\title{
Toplumsal Sorunların Çözümüne Katkısı ve Karşılaşılan Engeller Açısından Duyuşsal Alanın Değerlendirilmesi
}

\author{
Doç. Dr. Etem YEŞİLYURT* \\ Atatürk Üniversitesi, Kazım Karabekir Eğitim Fakültesi, Erzurum / Türkiye
}

\section{$\ddot{\mathbf{O} z}$}

Toplumsal sorunların çözümüne katkısı ve karşılaşılan engeller açısından duyuşsal alanı değerlendirmek amacıyla yapılan bu çalışma nitel araştırma yaklaşımı çerçevesinde tasarlanmış ve durum çalışması deseni kullanılarak yürütülmüştür. Kolay ulaş1labilir durum örneklemesi yöntemiyle belirlenen çalışma grubunu 2015-2016 akademik yılı güz döneminde Konya ili merkez ilçelerinde yer alan iki ilkokul ve iki ortaokul düzeyinde görev yapan 44 öğretmen oluşturmaktadır. Yarı yapılandırılmış görüşme formu ile elde edilen veriler NVivo 8.00 nitel veri analizi programı kullanılarak içerik analiziyle çözümlenmiş, ortaya çıkan temalar ve bu temaların arasındaki bağlar, bir model şeklinde geliştirilmiştir. Uzman görüşü, katılımcı teyidi ve ayrıntılı betimlemeyle çalışmanın geçerliği, tutarlık ve teyit incelemesiyle de çalışmanın güvenirliği sağlanmıştır. Çalışmanın sonucunda; başta saygısızlık, bencillik, duyarsızlık, hoşgörüsüzlük, terör, trafik, toplumsal şiddet ve ekonomik sorunlar olmak üzere toplumda çok sayıda sorunun olduğu tespit edilmiştir. Öte yandan, öğretim programlarında toplumsal sorunların üstesinden gelecek birey yetiştirecek kadar duyuşsal alana yer verilmediği sonucuna da ulaşılmıştır. Ayrıca, bir öğretmenin 
bilişsel alanda yer alan davranışları öğrencilere kazandırmak kadar, duyuşsal alanda da yer alan davranışları da öğrencilere kazandırma sorumluluğu olduğu ortaya çıkmıştır. Ancak duyuşsal alanda yer alan davranışları öğrencilere kazandırma sürecinde öğretmenlerin başta âile ve medya kaynaklı olmak üzere okul ve arkadaş kaynaklı engellerle karşılaştıkları tespit edilmiştir.

Anahtar Kelimeler: Duyuşsal alan; Toplumsal sorunlar; Karşılaşılan engeller; İlkokul; Ortaokul; Öğretme.

\title{
Evaluation of the Affective Domain Based on Its Contribution to the Solution of Social Problems and Experienced Difficulties
}

\begin{abstract}
The goal of the study is to evaluate the affective domain based on its contribution to the solution of social problems and challenges. The study was conducted using the case study design and qualitative research approach. The study group consisted of 44 teachers working at the fall semester of 2015-2016. The study group was formed by convenience sampling method. The data collection tool contains a semi-structured interview form. The data was analyzed using 8:00 NVivo qualitative data analysis program, through the content analysis option. The validity of the study was enhanced through use of expert opinion, participants' confirmation, and detâiled description; while the reliability was fortified through consistency and confirmability analysis. Major problems were cited as: disrespect, selfishness, indifference, intolerance, terrorism, traffic and violence in society, social and economic issues. The findings have established that the amount of instruction in the affective domain prescribed by the curriculum was not sufficient for educating individuals who are able to overcome social problems. Teachers were responsible for providing instruction in the affective domain as well as the cognitive domain. However, during the process of providing instruction in the affective domain teachers have experienced problems caused by families, the media, school and peers.
\end{abstract}

Keywords: Affective domain; Social problems; Experienced difficul- 
ties; Elementary school; Secondary school; Teachers.

\section{Extended Summary}

\section{Purpose}

The review of the literature on the subject shows that a number of studies on the affective domain have been undertaken. However, there is a lack of research addressing the evaluation of the affective domain, in terms of its contribution to the solution of social problems and obstacles. The goal of the study is to evaluate the affective domain based on its contribution to the solution of social problems and challenges.

\section{Method}

The current study was conducted using the case study design and qualitative research approach. The study group consisted of 44 elementary and middle school teachers working at various schools located within districts of Karatay, Meram and Selçuklu, during the fall semester of 2015-2016. The study group was formed by convenience sampling method. The data collection tool developed by the researcher contains "a semi-structured interview form". The data was analyzed using 8:00 NVivo qualitative data analysis program, through the "content analysis" option. The validity of the study was enhanced through use of expert opinion, participants' confirmation, and detâiled description; while the reliability was fortified through consistency and confirmability analysis.

\section{Results}

The findings regarding the first sub-objective of study indicated 
that the society perceived the following as the most common problems: disrespect, selfishness, insensitivity, intolerance, terrorism, lack of spirituality, traffic, social violence and economic difficulties. On the other hand, lack of trust; injustice; media related issues; political division; substance addiction; moral corruption; deception and environmental pollution were also perceived as common problems by the society. Additionally, lack of empathy, domestic violence, illiteracy, thievery, lack of sympathy and unemployment were listed among the most common social problems. Furthermore, prejudice, profanity-slang, gossip, formalism, child abuse and unplanned urbanization have emerged among the major social problems. On the other hand, anger, favoritism, adulation, flattery and divorce have less frequently emerged among the problems experienced in society.

Participants indicated that they were bothered by societal problems. The point highlighted by the participants was that the amount of instruction in the affective domain prescribed by the curriculum was not sufficient for educating individuals who are able to overcome social problems. The most significant among the suggested solutions for this problem entails: reduction of the time devoted to cognitive domain in the curriculum, teachers who are open to innovation, parental involvement in the education process and presence of positive role models. They are followed by basing instruction more on activities, introduction of known characters as role models and providing opportunities for extracurricular activities.

With regard to the fourth sub-objective of the study where the 
question was "Is the teacher responsible for providing instruction in the affective domain?". The findings indicate that addressing the affective domain is among the tasks of the teacher. Among their responsibilities with regard to the affective domain-relate behavior, serving as role models, ensuring parental involvement in the process, and fulfilling their professional obligations were cited as fundamental. Moreover, valuing and assigning responsibilities to students as well as utilizing case studies in teaching were seen among teacher's responsibilities regarding education in the affective domain. On the other hand, providing time and space for extra-curricular activities, teaching our national and moral culture, using reward-reinforcement in class, assigning group work were also among the tasks of teachers in affective domain.

In relation to the fifth sub-objective of the study, lack of parental support and the media, followed by school and peer-related issues were identified as major obstacles preventing teachers from fulfilling their affective domain- related responsibilities. Findings indicate that family-related obstacles hindering affective based education include (in the order of importance): parents' lack of recognition of affective-domain related responsibilities; apathy; excessive intervention; conflict between school and family values; presence of domestic violence; lack of attention to teaching respect and responsibility; and not being a role model for their children. Moreover, these family-oriented obstacles were followed by families' focus on cognitive-academic achievement and negligence of the affective domain; conflicting values among family members; lack of effective parent-child communication; 
family break-up/divorce.

\section{Discussion}

The media-related obstacles preventing teachers from carrying out their responsibilities regarding the affective domain include the media's negative impact on people, lack of quality programs; presentation of morally un-fit characters as role models. The list of media-related obstacles continued with leading to waste of time; lack of media literacy; moral degeneration, misleading and conflict of values induced by the media. Based on the findings, school related obstacles preventing the fulfillment of affective domain related responsibilities include: lack of parent-school communication; excessive focus and emphasis on the cognitive domain; lack of discipline; discrepancy among teachers' attitudes regarding the affective domain. School related obstacles preventing the fulfillment of affective domain related responsibilities mentioned above were followed by: lack of administrative support; lack of recognition of the affective domain as a part of the curriculum; and excessive emphasis on school discipline. According to the study, among the peer-based obstacles preventing the fulfillment of affective domain related responsibilities peer-pressure and negative influence were emphasized. Other peer related issues include: emulating unfit role models and comparison of self with peers who display unwanted behavior with a desire to justify their stance.

\section{Conclusion}

In general, the results of the study have revealed that there are a considerable number of social problems. Major problems were cited as: 
disrespect, selfishness, indifference, intolerance, terrorism, lack of spirituality, traffic, and violence in society, social and economic issues. On the other hand, the findings have established that the amount of instruction in the affective domain prescribed by the curriculum was not sufficient for educating individuals who are able to overcome social problems. Furthermore, it was concluded that teachers were responsible for providing instruction in the affective domain as well as the cognitive domain. However, during the process of providing instruction in the affective domain teachers have experienced problems caused by families, the media, school and peers.

\section{Giriş}

Nitelikli insan ve toplum, bugünkü eğitim sistemlerinin temel misyonu hâline gelmiştir. Eğitimin amacı doğrultusunda işletilen eğitim sitemlerinin ürün (sonuç, çıktı) olarak ortaya koyduğu istendik davranışlar ile gerçek hayatta bazı durumlarda ve zamanlarda karşılaşılan davranışlar arasında farklar olabilmektedir. Nitekim temel amacı iyi insan, iyi vatandaş yetiştirmek olan ilköğretim (ilkokul) dönemi eğitim kademesinin zorunlu ve hemen hemen bütün vatandaşlarının ilköğretim mezunu olduğu ülkemizde terörden, madde bağımlılığına, âile içi şiddetten, güven bunalımına kadar geniş bir yelpazede yaşanılan sorunlar, yukarıda ifade edilen durumu açıklar niteliktedir. Bu durumun temel nedenlerinden birini, öğretim sürecinin genel ilkelerinden biri olan bütüncüllük ilkesine eşit ağırlık vermemekten kaynaklanmaktadır. Nitekim bir insanı veya bir toplumu nitelikli yapan unsur, insanın ve toplumun bütün bireylerinin hem bi- 
lişsel, hem duyuşsal hem de psiko-motor alanda yer alan davranışların tamamında yani bütüncül bir yaklaşımla istendik yönde bir değişikliğgin olmasıyla mümkündür.

Başta Bloom, Krathwohl, Masia, Simpson, Anderson olmak üzere bazı eğitim bilimciler, davranışı bilişsel, duyuşsal ve psiko-motor olmak üzere üç alan hâlinde ele almışlardır (Yeşilyurt, 2012). Bilişsel alan, zihinsel yetilerin kodlandığı alan ya da zihinsel yönü ağır basan öğrenmeler olarak tanımlanmaktadır (Demirel, 2012). Duyuşsal alan ilgi, tutum, sevgi, nefret, güdüleme, alışkanlık vb. değer yargılarıyla ilgili olan, psiko-motor alan ise zihin ve kas eşgüdümünü gerektiren becerilerin ağırlıkta olduğu öğretim hedeflerini içermektedir (Sözer, 2003). Duyuşsal alan; ilgi, tutum, değer, öz-yeterlik, güven, inanç, güdülenmişlik, kaygı, benlik, sevgi, korku, ulusal ülkülere bağlılık, hoşgörülü olma, çevreyi temiz tutma, zamanı etkili kullanma gibi çeşitli duygu ve davranış tarzlarını içermektedir. Akbaş (2008), insanlara karşı saygı göstermek, hoşgörülü olmak, çalışkan olmak ve vatansever olmak gibi değerler, kendisine yapılmasını istemediği bir şeyi başkasına yapmama gibi ahlâkî ilkeler duyuşsal alan boyutunda olduğunu belirtmektedir. $\mathrm{Bu}$ üç alan birbirinden tamamıyla soyutlanamaz. Bir amaç bütünüyle bilişsel, psiko-motor ya da duyuşsal alana girmeyebilir. Amaç, bilişsel özellikleri ağır basıyorsa bilişsel, psiko-motor özellikleri ağır basıyorsa psiko-motor, duyuşsal özellikleri ağır basıyorsa duyuşsal olarak sınıflanmaktadır. Akpınar'a (2013, s.132) göre, duyuşsal alana yönelik olarak Krathwohl tarafından yapı- 
lan sınıflama en çok kullanılan sınıflama olup, bu alanda yer alan davranışların merhaleli sınıflaması ve genel özellikleri şu şekildedir:

Alma (Farkında Olma): Bireyin dikkatini yönelterek herhangi bir uyarıcıyı fark etmesi ve ayırt etmesi davranışlarını kapsar. Farkında olma, almaya açıklık, seçici dikkat, ilgi duyma, duyarlı olma vb. şekillerde kendisini gösterebilir. Örnek: "Okul kurallarının farkında oluş”, "Öğrenim gördüğ̈̈̈ alanla ilgili yayınları seçmede dikkatli oluş”, “Konuşanın sözünü kesmeden dinleme”.

Tepkide Bulunma (Razı Olma-Cevap Verme): Bireyin her hangi bir uyarıcıya karşı uysal davranmasl, ona karşı istek duyması ve ondan zevk alması davranışlarını kapsar. Önceki basamakta uyarıcının sadece farkında olan birey, bu basamakta uyarıcıya karşı bilinçli ve isteyerek tepki verir. Örnek: "Eğitim ve öğretim kurallarına uymaya razı oluş/uymaktan zevk alış”, "Verilen görevi itiraz etmeden gerektiği gibi yapma”.

Değer Verme (Takdir Etme): Bu basamakta bireyin, bir inanç, tutum, değeri samimiyetle kabullenmesi, başkalarına tercih etmesi ve bu değere kendini adamasi söz konusudur. Bu basamakta taraftar olma, adanma, kabullenme söz konusudur. Önceki basamakta istek duyulan davranış, bu basamakta, tutum ve inanç hâline gelir. Fakat benimsenen değer bütünüyle kendince oluşturulmuş değildir. Örnek: "Fen laboratuvarındaki araç ve gereçlerin önemini takdir etme”, "Fen laboratuvarındaki araç ve gereçleri korumayı kendine iş edinme”, "Çevre bilinciyle ilgili toplantılar düzenleme".

Örgütleme (Düzenleme): Bu basamakta, bireyin bir değeri takdir etmekten öteye geçerek, bu değeri kendine mal etmesi söz konusudur. Değer sistemine katma, yeni değerler oluşturma. Böylece birey, kendine mal ettiği değerleri yeniden düzenleyerek bir anlamda yeni değerler oluşturur (düzenleme). Söz konusu değeri benimsemede kararlılık gösterir (kararlı olma) ve be- 
nimsediği dĕgerin uygulanmasını să̆lamaya çaba gösterir. Örnek: "Fen laboratuvarındaki araç ve gereçleri korumada kararlılık”, "Kendine yapılan eleştirileri dikkate alma”.

Kişilik Hâline Getirme (Karakterize Etme-KişileştirmeNitelenmişlik): Bir değer/değerler bütünüyle nitelenmişlik. Bu basamakta bireyin savunduğu değeri kişilik hâline getirerek içselleştirmesi söz konusudur. Kişi, bu basamakta sâhip olduğu inancı değişmez bir hayat felsefesi olarak benimser, allşkanlık hâline getirerek onu yaşar. Bireyin herhangi bir değere dünya görüşünde yer veriri ve davranış ölçütü hâline getirir Bu düzeye yetişkinliğe kadar ulaşılamaz. Örnek: “Öğrenciler arasında ayrım yapmamayı hayat felsefesi hâline getirme”, "Çevreyi tahrip edenlere her zaman karşı çıkma"

Bireylerin kendilerini sadece bilişsel açıdan donanımlı hâle getirmeleri elbette ki yeterli olmayacaktır. Bu durumun önüne geçmek amaciyla bireylerin hem bilişsel hem duyuşsal hem de psiko-motor alanda yer alan davranışların tamamında tatmin edilmesi ve donanımlı hâle getirilmesi gerekmektedir. $\mathrm{Bu}$ nedenle birbirinden ayrı düşünülemeyecek ve geleceğin belirleyicisi konumundaki eğitim ve öğretimin duyuşsal boyutuna ilişkin daha fazla çabanın gösterilmesi gerekli görülmektedir (Gömleksiz ve Kan, 2012). Teorik alt yapıda ve anlamda Türk millî eğitim sistemi bu üç alanın tamamına, açık ve net olarak da duyuşsal alana önem vermektedir. Nitekim bilişsel, duyuşsal ve psiko-motor alanlara göre analiz edildiğinde 1739 sayılı Millî Eğitim Temel Kanunu'nda (MEB, 2015), Türk millî eğitiminin genel amaçları arasında yer alan duyuşsal alan özellikleri şöyle özetlenebilir:

$\checkmark$ Insan haklarına saygl, 
Kişilik ve teşebbüse değer verme,

Topluma karşı sorumluluk duyma,

Geniş bir dünya görüşüne sâhip olma,

Birlikte iş görme alışkanlığı kazanma,

$\checkmark$ Ailesini, vatanını, milletini sevme ve daima yüceltmeye çalışma,

$\checkmark$ Atatürk inkllaplarına ve anayasanın başlangıcında ifadesini bulan Türk milliyetçiliğine bağlılık,

$\checkmark$ Türk Milleti'nin millî, ahlâkî, insanî, manevî ve kültürel değerini benimseme, koruma ve geliştirme,

$\checkmark$ Ahlâk, ruh ve duygu bakımlarından dengeli ve sağlıklı şekilde gelişmiş kişilik ve karakter özelliklerine sâhip olma,

$\checkmark$ Kendisini mutlu kılacak ve toplumun mutluluğuna katkıda bulunacak bir meslĕgin gerektirebilecĕgi diğer özelliklere sâhip olma.

Okulda verilecek eğitimde bilişsel öğrenmelerle, duyuşsal öğrenmeler arasında yüksek düzeyde bir ilişki vardır. Duyuşsal giriş özellikleri, öğrenme ürünlerindeki değişikliğin \%25'ini açıklama gücündedir. Öte yandan bilişsel giriş davranışlarının ve duyuşsal giriş özelliklerinin birlikte başarı dağılımını açıklama oranı ise \%65 olarak ifade edilmektedir (Senemoğlu, 2013). Konuyla ilgili yapılan bir araştırma bu kuramsal bilgiyi doğrulamaktadır. Uluslararası Matematik dersi değerlendirme araştırmasında matematik dersiyle ilgili duyuşsal özellikler ile başarı arasında anlamlı bir ilişki olduğu tespit edilmiştir. $\mathrm{Bu}$ araştırmadan elde edilen sonuçlara göre, başarıda gözlenen toplam 
değişkenliğin \%12-20 arasındaki bir kısmı dersle ilgili duyuşsal özelliklerdeki farklarla açıklanmaktadır (Akşid ve Şahin, 2011). Ancak, bilişsel alanın özellikle bilgi basamağında sayılabilecek bazı ögeler olmadan duyuşsal alandaki davranışlar gerçekleşmeyebilir (Erden, 1998). Çünkü bilmediğimiz bir olguya karşı herhangi bir sevgi, nefret, korku vb. gibi duyuşsal bir tepki geliştiremeyiz (Sönmez, 2007; Sünbül, 2011). Duyuşsal öğrenme, yaşantıları okul ortamında kazanılan yeterliklerin yanı sıra, âilede ve toplumsal hayat içerisinde de elde edinilen kazanımlardır (Taşpınar, 2012). Bu nedenle duyuşsal alanla ilgili davranışların tek sorumlusu okul olmamakla birlikte, yine de okulda bu istendik davranışların kazandırılmasına yönelik uygulamaların bulunması zorunludur. Bazı durumlarda toplumda yer alan duyuşsal davranışlar ile okulda kazandırılmaya çalışılan duyuşsal davranışların birbiriyle çelişsebilmektedir. Meselâ "Devletin malı deniz, yemeyen domuz.” yargısının yaygın olduğu bir toplumda, bunun karşıtı ve toplumun geneli tarafından da istenilen bir davranışı öğrencilere kazandırmak zordur (Sönmez, 2007). Kısaca duyuşsal alan okul içerisinde ve okul dişında zaman ve mekânların ortak ürünüdür. Bu durum bir yandan duyuşsal alanda yer alan davranışların bireylere kazand1rılmasındaki zaman ve mekân kavramının genişliğine, diğer yandan da zorluğuna işaret etmektedir. Konuyla ilgili olarak Bacanlı (2005), duyuşsal alanda yer alan hedeflerin ihmal edilme ve öğrencilere kazand1rılmasında karşılaşılan zorlukların sebeplerini şöyle sıralamaktadır:

Duyuşsal hedeflerin;

$\checkmark$ Öğretimi uzun sürmektedir, 
$\checkmark$ Alışılmış ögretim yöntemleri ile sonuç almak zordur,

$\checkmark$ Değerlendirilmesi alışılmış "başarı" anlayışının dışındadır,

$\checkmark$ Değerlendirilmesi bilişsel hedeflerin değerlendirilmesine göre daha esnektir,

$\checkmark$ Konusunda uzlaşılması, somutlaştırılması, ölçülmesi ve değerlendirilmesi zordur,

$\checkmark$ Kazandırlmasında paydaşlar çoktur, paydaşlar arasında görev tanımları açık değildir.

\section{Araştırmanın Önemi}

Son yıllarda dünyada yaşanan savaşlar, artan şiddet olayları, bağımlılık yapan uyuşturucu maddelerin kullanımının yaygınlaşması, âile bağlarının zayıflaması, insanlar arası güven ortamının bozulması gibi sorunların ortadan kaldırılması, her toplumun öncelikli hedefleri hâline gelmiştir. Bu bağlamda 2004 yılından itibaren ülkemizde öğretim programlarının güncellenmesine gidilmiş ve bu güncellemenin ana temellerinden birini de öğretim programlarında duyuşsal alana biraz daha fazla ağırlık verilmesi oluşturmuştur (Yiğittir ve Kaymakcı, 2012). Ancak, öğretim programları genel olarak incelendiğinde, öğrencilerde görülmek istenen kazanımların büyük ölçüde bilişsel alanla ilgili olduğu dikkat çekmektedir (Erdoğan, 2007; Özdemir, Altık ve Baki, 2015; Şahin, 2007; Tahaoğlu, 2014; Yıldız ve Bümen, 2013). Dolayısıyla öğretim programlarında öğrencilerin akademik başarıları (bilişsel alan) üzerinde ciddi biçimde durulurken, onların duyuşsal alan becerileri üzerine programlı ve sistematik biçimde yeterince durulmamış, ya göz ardı edilmiş ya da unutulmuştur. Öğrencilerin duyuşsal becerilerinin yeterince gelişmemesinden dolayı ortaya 
çıkan kişiler arası çatışmalar ve öğrenci istenmeyen davranışlarının nedenleriyle ilgilenilmek ve bu nedenlerin ortadan kaldırılması yerine uyarma, kınama, okul değiştirme gibi yetişkin baskısını, otoritesini, korkuyu ve tehdidi vurgulayan yöntem ve tekniklerle sorunlu davranışları ortadan kaldırmaya çalışılmıştır. Bu durum aynı zamanda yönetmeliklerle de yasal anlamda desteklenmiştir. Buna karşın sorunların asıl nedenlerinden birisi olan duyuşsal alanda öğrencilerin yeterince gelişmemiş olması üzerinde ya durulmamıştır ya da göz ardı edilerek ikinci plânda kalmıştır (Türnüklü, 2004). Bu durum, Bloom taksonomisi, kazanımlar, öğretim programlarında bilişsel, duyuşsal ve psiko-motor alanları ile benzeri konularda yapılan çalışmalarda da somut olarak resmedilmektedir.

Nitekim, alanyazın incelendiğinde, tarih (Semerci ve Özer, 2004), fen bilgisi (Çakır, Şahin ve Şahin, 2000), fen ve teknoloji (Erişti ve Tunca, 2012), beden eğitimi (Çelen, Mirzeoğlu ve Mirzeoğlu, 2010; Güllü, Arslan, Uğraş ve Görgüt, 2011) ve ilköğretim (Başar, 2009; Otluoğlu, 2002) öğretim programları bağlamında duyuşsal alanla ilgili çalışmaların yapıldığı görülmektedir. Bunların yanı sıra okul öncesi duygusal gelişim (Ceylan ve Ömeroğlu, 2012), duyuşsal alanla ilgili ölçek geliştirme (Gömleksiz, 2003), öğretim yöntemlerinin duyuşsal alana etkisi (Morgil, Güngör-Seyhan ve Seçken, 2009; Yeşilyurt, 2013a), duyuşsal alan kazanımların tasarlanması (Ayvacı, Alev ve Yıldız, 2015) ile duyuşsal giriş özelliklerinin öğrenmeye etkisi (Çalışkan, 2014) konuları üzerine yapılan çalışmalar da alanyazında yer almaktadır. Ancak toplumsal sorunların çözümüne katkısı ve 
karşılaşılan engeller açısından duyuşsal alanın değerlendirilmesine ilişkin herhangi bir araştırmaya ulaşıl(a)mamıştır. $\mathrm{Bu}$ araştırma kapsamında, toplumda sıkça yaşanılan sorunlar, öğretim programlarında duyuşsal alana verilen yer, bir öğretmenin duyuşsal alana yönelik görevleri ve bu görevlerini yerine getirirken karşılaştıkları engellerin neler olduğu bütüncül bir bakış açısıyla ortaya konulmuştur. $\mathrm{Bu}$ çalışmanın hem diğer çalışmalardan farklı ve özgün olduğunu göstermekte hem de alana katkı yapacağı umulmaktadır.

\section{Araştırmanın Amacı}

Araştırmanın amacı, toplumsal sorunların çözümüne katkısı ve karşılaşılan engeller açısından duyuşsal alanı değerlendirmektir. $\mathrm{Bu}$ genel amaç doğrultusunda aşağıdaki sorulara cevap aranmıştır.

1. Toplumda görülen en önemli toplumsal sorunlar nelerdir?

2. Toplumda görülen sorunlar katılımcıları rahatsız etmekte midir?

3. Toplumsal sorunların üstesinden gelecek birey yetiştirecek kadar öğretim programlarında duyuşsal alana yer verilmekte midir?

4. Bir öğretmenin duyuşsal alana yönelik görevleri var mıdır?

5. Bir öğretmenin duyuşsal alana ilişkin görevlerini yerine getirmesinde karşılaştığı engeller nelerdir? 


\section{Yöntem}

\section{Araştırma Deseni}

Çalışma, nitel araştırma yaklaşımı çerçevesinde tasarlanmış ve “durum çalışması” deseni kullanılarak yürütülmüştür. Yıldırım ve Şimşek'e (2006) göre durum çalışmasında amaç belirli bir duruma ilişkin sonuçları ortaya koymak olduğundan sonuçların farklı durumlara genellemesi söz konusu değildir. Dolayısıyla bu çalışmada toplumsal sorunların çözümüne katkısı ve karşılaşılan engeller açısından duyuşsal alan değerlendirmeye çalışılmıştır.

\section{Çalışma Grubu}

Araştırmanın çalışma grubunu, 2015-2016 eğitim-öğretim yılı güz döneminde Konya ili Karatay (ilkokul ve ortaokul), Meram (ilkokul) ve Selçuklu (ortaokul) merkez ilçelerinde yer alan ilkokul ve ortaokul düzeyinde görev yapan 44 öğretmen oluşturmaktadır. Çalışma grubunun belirlenmesinde öncelikle sosyolojik ve ekonomik yapı ile disiplin sorunları açısından ilçelerin genel durumunu yansıtan okullar belirlenmiş olup ve okullar içerisinden "kolay ulaşılabilir durum örneklemesi" yöntemi kullanılarak çalışma grubu seçilmiştir. Kolay ulaŞılabilir durum örneklemesinde araştırmacı yakın ve erişilmesi kolay olan bir durumu seçmektedir (Yıldırım ve Şimşek, 2006). Çalışma grubunda yer alan katılımcıların cinsiyet değişkeni açısından $\% 54.55$ 'i (f=24) kadın, \%45.45'i ( $\mathrm{f}=20)$ erkektir. Görev yapılan okul türü değişkeni açısından katılımcıların \%52.27'si (f=23) ilkokul, \%47.73'ü $(\mathrm{f}=21)$ ortaokul kademesinde görev yapmaktadır. Branş değişkenine göre \%25'i (f=11) sınıf öğretmeni, \%13.63'ü (f=6) Türkçe öğretmeni, 
diğer branşlar da ise bu oran toplamda \%61.37 olup, her branştan (matematik, ingilizce, fen bilgisi, sosyal bilgiler, bilişim teknolojileri, din kültürü ve ahlak bilgisi, teknoloji ve tasarım, beden eğitimi öğretmeni, rehberlik ve psikolojik danışman) üç öğretmen alınmıştır. Meslekî kıdem değişkenine göre ise katılımcı grupta yer alan öğretmenlerin \%29.55'i (f=13) 1-10 y1l aras1, \%47.72'si (f=21) 11-20 y1l aras1, $\% 22.72$ 'si (f=10) 21 yıl ve üzeri kıdemde yer almaktadır.

\section{Veri Toplama Aracı}

Çalışmanın amacı doğrultusunda araştırmacı tarafından geliştirilen veri toplama aracı iki bölümden oluşmaktadır. "Yarı yapıland1rılmış görüşme formu" niteliği taşıyan veri toplama aracının birinci bölümünde katılımcıların demografik özelliklerini belirlemeye yönelik dört soru, ikinci bölümünde ise toplumsal sorunların çözümüne katkısı ve karşılaşılan engeller açısından duyuşsal alanın değerlendirilmesine yönelik beş soru yer almaktadır. Çalışmanın amacına uygunluğu, açıklığı ve anlaşılırlığı açısından iki alan bilgisi ve bir dil bilgisi uzmanın görüşüne sunulan form, uzman görüşleri doğrultusunda küçük bir değişiklikle uygulama hâlini almıştır. $\mathrm{Bu}$ yol kullanılarak, veri toplama aracının kapsam ve görünüş geçerliği sağlanmaya çalış1lmıştır. Çünkü Büyüköztürk’e (2007) göre, bir ölçme aracının kapsam ve görünüş geçerliği uzman görüşleriyle değerlendirilebilir.

\section{Verilerin Toplanması}

Nitel çalışmada en önemli özelliklerden birisi, katılımcıların kendilerinden neler beklendiği, sorulara cevap verirken nelere dikkat edilmesi gerektiği konusunda bilgi sâhibi olmalarıdır. Bu nedenle veri 
toplama aracının yönergesinde, araştırmanın amacı, formun nasıl doldurulacağı ve “duyuşsal alan” kısaca tanımlanmış ve birkaç örnek verilmiştir. Ayrıca, veri toplama süreci doğrudan araştırmacı tarafından işletilmiş olup araştırmanın önemi ve kapsamı, bu kapsamda kullanılan görüşme formu ve nasıl doldurulması gerektiği konusunda çalışma grubuna doğrudan bilgi sunulmuştur. Veri toplama arac1, 12-16 Ekim 2015 tarihleri arasında araştırmaya gönüllü olarak katılan öğretmenlere uygulanmış olup, uygulama süreci katılımcı başı ortalama yarım saat sürmüştür.

\section{Verilerin Analizi}

Veri toplama aracından elde edilen veriler öncelikle Microsoft Word programına yazılmış ve bilgisayara kaydedilmiştir. Daha sonra bilgisayar aracılığıyla NVivo 8.00 nitel veri analizi programına aktarılan veriler “içerik analizi” yle çözümlenmiştir. İçerik analizi, birbirine benzeyen verileri belirli kavramlar ve temalar çerçevesinde bir araya getirmek ve bunları okuyucunun anlayacağı biçimde düzenleyen bir veri çözümleme yöntemidir (Yıldırım ve Şimşek, 2006). Öte yandan Mayring (2000) içerik analizinin dilsel materyal ve metinlerin sistematik olarak analizine, materyallerin bölme ve aşamalı olarak incelenmesine, çözümleme boyutlarının materyalin kuramsal olarak kategorileştirilmesi yoluyla önceden belirlenmesine firsat tanıdığını ileri sürmektedir.

Verilerin içerik analiziyle çözümlenmesi sonucunda, ortaya çıkan temalar ve bu temaların arasındaki bağlar, bir model şeklinde geliştirilmiştir. Modeldeki ilişkileri göstermek için ok yönü ve kalınlığı dik- 
kate alınmıştır. Okların kalınlığının belirlenmesinde, ilgili tema için yapılan yükleme (atıf) sayısı dikkate alınmıştır. Ok kalınlığı için elde edilen sayısal değer 1n-5n aralığına göre belirlenmiş ve ok kalınlıklarının belirlenmesinde şu yol takip edilmiştir. Öncelikle ilgili modelde yer alan temalar için yapılan yükleme (atıfta bulunulan görüşlerin) sayısı toplanmış ve elde edilen sayı beşe bölünmüştür. Bu işlemi takiben ortaya çıkan sayısal değer (n) temel alınmış olup, bu değer 1xn, $2 \mathrm{xn}, 3 \mathrm{xn}, 4 \mathrm{xn}$ ve $5 \mathrm{xn}$ şeklinde işleme tabi tutulmuş ve yeni bir sayısal değer elde edilmiştir. Ulaşılan bu sayısal değer, her bir tema için yapılan yükleme sayısıyla karşılaştırılmış ve 1n-5n aralığına göre ok kalınlıkları belirlenmiştir. Temalar için belirlenen ok kalınlığı artması, ilgili tema için yapılan yükleme sayısının da aynı oranda artması anlamını taşımaktadır. Ancak bazı temalarda atıf sayısı az olduğu için hangi temanın daha fazla atıf aldığını daha net belirlemek için, atıf sayısı en fazla olan tema dikkate alınarak diğer temalarda aynı oranda arttırılmış ve böylece ok kalınlıkları daha anlaşılır şekle sokulmuştur.

Yıldırım ve Şimşek'e (2006) göre, nitel araştırmalarda uzman görüşü, katılımcı teyidi ve ayrıntılı betimlemeyle çalışmanın geçerliği; tutarlık ve teyit incelemesi ise çalışmanın güvenirliği artırılabilir. $\mathrm{Bu}$ nedenle, çalışmanın geçerliğini yükseltmek için ortaya çıkan sonuçlar çalışma grubunda yer alan üç katılımcının teyidine sunulmuş ve benzer görüş elde edilmiştir. Çalışmanın güvenirliğini yükseltmek için dışarıdan bir uzmana araştırmanın ham verileri verilmiş ve verileri çözümlemesi istenmiştir. Daha sonra onun ulaştığı sonuçlar ile bu araştırmadan ortaya çıkan sonuçların tutarlığına bakılmış ve birbirini des- 
tekler bulgu ve sonuçlara ulaşılmıştır. Öte yandan, çalışmanın bulguları, ilgili tema içerisinde yer alan görüşlerin genelini yansıtacak şekilde doğrudan yapılan alıntılarla desteklenmiş ve çalışma niteliğinin yükseltilmesine önem verilmiştir.

\section{Bulgular}

Bu bölümde araştırmanın alt amaçları dikkate alınarak elde edilen bulgulara yer verilmiştir.

\section{Toplumda Görülen En Önemli Toplumsal Sorunlara İlişkin Çö-} zümlemeler

Katılımcıların görüşleri doğrultusunda, toplumda görülen en önemli sorunlar ilişkin model Şekil 1'de yer almaktadır.

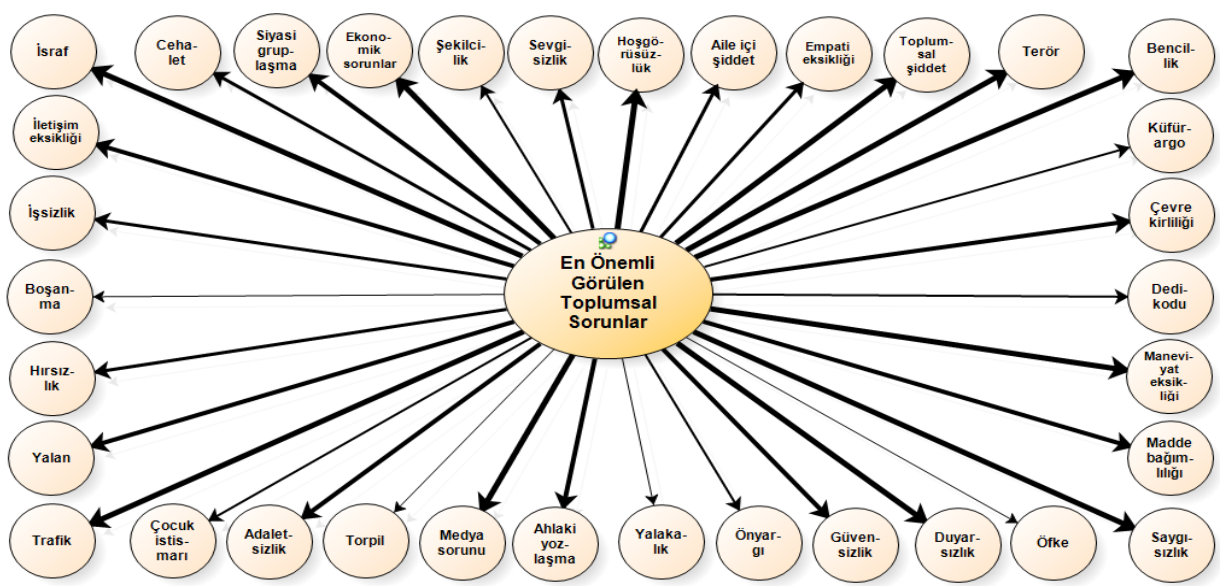

Şekil 1. Toplumda görülen en önemli toplumsal sorunlara ilişkin şematik gösterim.

Verilerin çözümlenmesi sonucunda toplumda en fazla görülen sorunlar arasında ilk sırada; saygısızlık, bencillik, duyarsızlık, hoşgörüsüzlük, terör, maneviyat eksikliği, trafik, toplumsal şiddet ve ekonomik sorunlar yer almaktadır. Bu sırayı güvensizlik, adaletsizlik, 
medya sorunu, siyasî gruplaşma, madde bağımlılığı, ahlâkî yozlaşma, yalan ve çevre kirliliği sorunları takip etmektedir. Katılımcıların görüşlerine göre, empati eksikliği, âile içi şiddet, cehalet, hırsızlık, sevgisizlik ve işsizlik de en fazla görülen toplumsal sorunlar arasında yer almaktadır. Önyargı, küfür-argo, dedikodu, şekilcilik, çocuk istismarı ve çarpık kentleşme de katılımcılar tarafından toplumsal sorunlar arasında gösterilmiştir. En az yükleme (atıf) sayısına sâhip olsa da kat1lımcılar tarafından öfke, torpil, yalakalık-yağcılık ve boşanma da toplumda yaşanılan sorunlar arasında gösterilmiştir.

\section{Toplumda Görülen Sorunların Katılımcıları Rahatsız Etmesine İlişkin Çözümlemeler}

Toplumda görülen sorunların katılımcıları rahatsız etmesine ilişkin katılımcıların görüşlerinin nitel çözümlemesi sonucunda elde edilen model Şekil 2'de yer almaktadır. Ayrıca, toplumda görülen sorunların katılımcıları rahatsız etmesine ilişkin elde edilen görüşlerden oluşturan ve yükleme (ilgili temaya yapılan atıf sayısı) sayısı en fazla olan temalar ve bu temalar içerisinde yer alan görüşlere aşağıda detaylı olarak yer verilmiştir. 


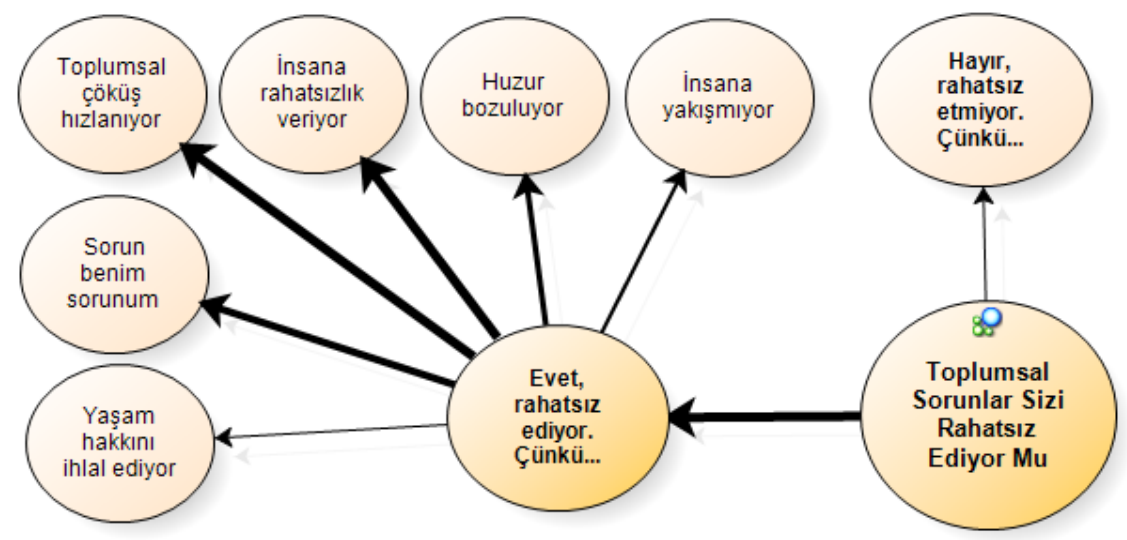

Şekil 2. Toplumda görülen sorunların katılımcıları rahatsız etmesine ilişkin şematik gösterim.

\section{Evet, rahatsız ediyor. Çünkü...}

Katılımcıların tamamı, toplumda görülen sorunların kendilerini rahatsız ettiğini belirtmiş olup nedenlerine ilişkin elde edilen temalar aşağıda yer almaktadır.

\section{Toplumsal çöküsş hızlanıyor.}

Nitel analiz sonucunda en fazla yüklemenin “Toplumsal çöküş hızlanıyor." temasına yapıldığı tespit edilmiştir. Bu bağlamda katılımcılar, toplumda görülen sorunların, toplumun çöküşünü hızlandırdığına vurgu yapmıştır. Bu temaya referans olan katılımcıların bazılarının görüşleri aşağıda örneklendirilmiştir:

Bu toplumun bir parçasıyız toplumdaki herhangi bir çatırdama bizi ve bütünümüzü olumsuz yönde etkileyeceği için toplumsal sorunlar beni rahatsız ediyor, toplumun çöküşünü hızlandırır. (Katılımcı numarası: 7) 
Bana dokunmayan yılan bin yaşasın anlayışında olmamak gerektiğine inaniyorum. Toplum vücut gibidir. Bir yerdeki rahatsızlık, başka bölgeleri de sarsabilir ve toplum çökebilir. (Kat1lımcı numarası: 12)

Ben o toplumun içinde yaşlyorum. O toplumda olan her şey beni yakından ilgilendirir. Bir yerde var olan kanayan bir yara, diğer yerdeki insanı da etkiler. Tam tersine ben bu sorunlardan rahatsiz olmayan insana şaşarım. Toplum bir ada ve bizler o adanın parçalarıyız. $O$ adada var olan sevinçler çı̆̆lıklar, feryatlar, açlık, zafer, yenilgi... Nasıl onun parçalarını etkilemez ki! (Kat1limc1 numaras1: 19)

\section{Insana rahatsızlık veriyor.}

Katılımcılar tarafından ikinci sırada en fazla yükleme "İnsana rahatsızlık veriyor.” temasına yapılmıştır. Bu noktada katılımcıların, toplumda görülen sorunların insan rahatsızlık verdiğini vurguladıkları görülmektedir. Bu temaya referans olan katılımcıların bazı görüşleri şu şekildedir:

Bizler birey olarak toplumları oluştururuz. Toplumsal sorunlarda direkt bireyleri etkiler. Bu nedenle toplumsal sorunlardan rahatsızlı duyuyoruz. (Katılımcı numaras1: 9)

Karşılaştı̆̆ım her bir sorun beni hem psikolojik olarak yıpratıyor hem de işimdeki performansımı etkiliyor, zorlaştırıyor, beni acayip rahatsız ediyor. (Kat1lımc1 numarası: 39)

Toplumsal sorunları oluşturmasında toplum önemlidir. Benim de toplumun parçası olan öğrencileri ĕgitme gibi bir görevim olduğundan rahatsızlı duyuyorum. (Katılımcı numarası: 5) 


\section{Sorun benim sorunum.}

Toplumsal sorunların rahatsız etmesine ilişkin katılımcılar tarafından en fazla yüklemenin yapıldığı temalardan biri "Sorun benim sorunum.” temasıdır. Bu temaya referans olan bazı katılımcıların görüşlerine aşağıda yer verilmiştir:

Toplumun derdi benim derdim. Yetişen insanlarda payım olduğunu düşünerek en hassasiyet gerektiren meslek sâhibiyim. (Katılimc1 numarası: 21)

İşimiz insanlarl eğitmek. Insanlara ilgili ne kadar sorun varsa bizim işimiz de bir o kadar zor ve yorucu oluyor. Ayrlca bu sorunlar büyüdükçe geleceğe dâir kaygılarımız da artıyor. (Kat1limcı numarası: 25)

Sorun hepimizin, büyügünden küçüğüne, yaşlısından gencine herkesin o sorunun oluşmasında ya da çözümünde belli hakları, belli sorumlulukları vardır. Soruna göz yumarak ilerliyorsak ĕger sorun kimin canın yakmış, kimi incitmişse bizde hiçbir şey yapmayarak suçlu olmuşuzdur. Artık o vebale bizde ortağızdır. Sorunun çözümü için uğraşmamış, sorumluluklarımızı yerine getirmemişsek ahlanıp vahlanmaya bir şeyleri eleştirmeye, birilerini suçlamaya hakkımız yoktur. (Katılımcı numarası: 34)

\section{Huzur bozuluyor.}

Toplumsal sorunların katılımcıları rahatsız etmesine ilişkin en fazla yüklemenin yapıldığı temalardan biri "Huzur bozuluyor." temasıdır. Bu temaya referans olan katılımcıların bazılarının görüşlerine aşağıda yer verilmiştir:

Toplum huzuru azallyor, mutsuzluk vesilesi oluyor... (Kat1lımc1 numarasi: 16) 
Toplumun bir parçasıyım. Bütün sorunlar doğrudan ya da dolaylı bir şekilde beni de etkiliyor. Sorunlardan ziyade çözümsüzlüklere, tıkanmalara, sonuca götürmeyen iletişim-iletişimsizlikler yoruyor, anlamsızlaştırıyor. (Katılımcı numarası: 27)

Toplumda görülen sorunların katılımcıları rahatsız etmesine ilişkin görüşlerin çözümlemesi sonucunda elde edilen ve altı katılımcının görüş bildirdiği tema olan "İnsana yakışmıyor." temasına "İnsanların birbirine saygl ve hoşgörüleri çok azaldı. Tahammülleri yok. Küçük sorunlar çok büyütülüyor. Karşılıklı ilişkiler yok. İletişim, âileden başlayarak her kesimde azallyor, bu sorunlar insan yakışmıyor." (Katılımcı numarası: 27) görüşü örnek gösterilebilir. Öte yandan dört katılımcının görüşlerinden elde edilen "Hayat hakkını ihlâl ediyor." temasını ise: “Adl üstünde toplumda birlikte yaşıyoruz, yaşamak zorundayız. Hava kirliliğinden, çevre sorunlarından sadece buna sebep olanlar etkilenmiyor, herkesi, her canliyı etkiliyor. Duyarsiz ve tepkisiz, ilgisiz olanları da etkiliyor ama farkında değiller." (Katılımcı numaras1: 27) önermesi nitelemektedir.

\section{Öğretim Programlarında Duyuşsal Alana Verilen Yere İlişkin}

\section{Çözümlemeler}

Çalışma grubunda yer alan öğretmenlerin, toplumsal sorunların üstesinden gelecek birey yetiştirecek kadar öğretim programlarında duyuşsal alana yer verilmesine ilişkin görüşlerin nitel çözümlemesi sonucunda elde edilen model Şekil 3 'te yer almaktadır. Ayrıca öğretim programlarında duyuşsal alana verilen yere ilişkin elde edilen görüşlerden oluşturan ve yükleme (ilgili temaya yapılan atıf sayısı) sayısı en 
fazla olan temalar ve bu temalar içerisinde yer alan görüşlere detaylı olarak aşağıda verilmiştir.

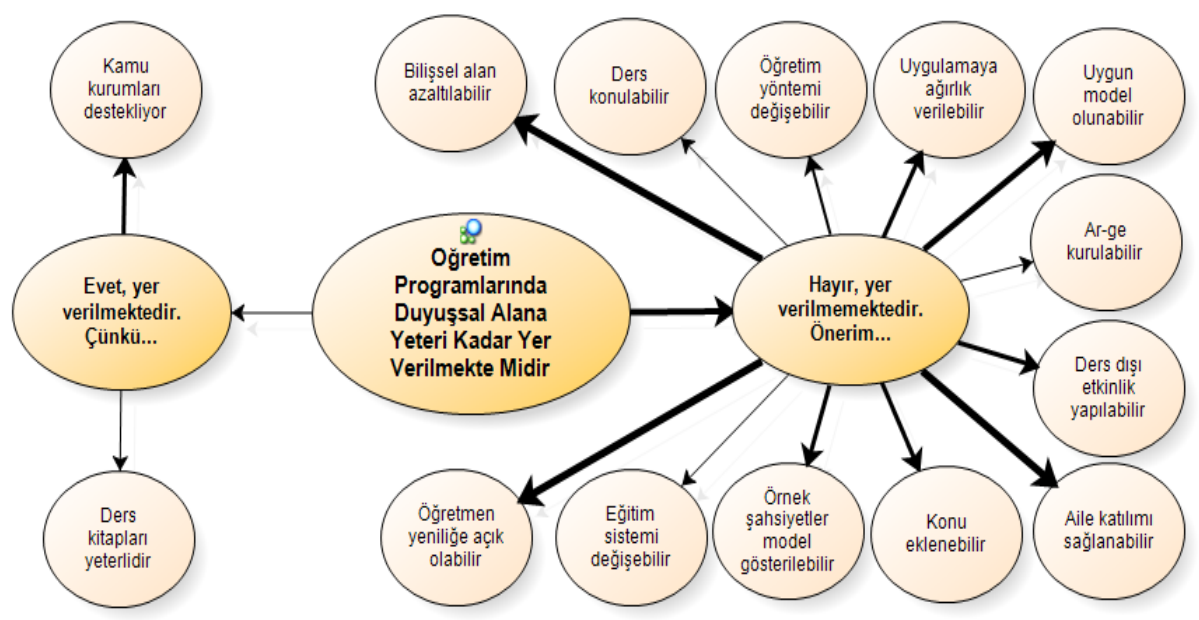

Şekil 3. Öğretim programlarında duyuşsal alana verilen yere ilişkin şematik gösterim.

\section{Hayır, yer verilmemektedir. Önerim...}

Çalışma grubunun görüşlerine dayanarak, toplumsal sorunların üstesinden gelecek birey yetiştirecek kadar öğretim programlarında duyuşsal alana yeteri kadar yer verilmediği tespit edilmiş ve oluşturulan temalara aşağıda ver verilmiştir.

\section{Bilişsel alan azaltulabilir.}

Nitel analiz sonucunda en fazla yüklemenin "Bilişsel alan azaltılabilir." temasına yapıldığ ler, öğretim programlarında duyuşsal alana yeteri kadar yer verilebilmesi için öncelikle bilişsel alanın daraltılması (azaltılması) gerektiğini 
önermiştir. İlgili temaya referans olan katılımcıların bazılarının görüşleri aşağıda örneklendirilmiş̧ir:

Akademik konulara ağırlık vermek yerine öğrencilerin günlük hayatta karşılaştıkları sorunların çözümüne onları yönlendirecek bakış açılarına ağırlık verebilir. (Katılımcı numarası: 1)

Ne yazık ki yıllık plânı yetiştirme, konuları yetiştirme kaygısı içinde bireylere duyuşsal bazı birikimleri aktaramiyoruz. Ders saatleri dişında bu eksiklikler giderilmeli. (Katılımcı numarası: 10)

Müfredatın ağır olması nedeniyle ancak ders konuları işlemeye çallşsllyyor. Öğrencilere yeterli vakit ayrllamıyor. Bence çok bilgi vermek yerine onlar için en önemli olan eğitime daha çok zaman verilmeli. (Kat1lımc1 numarası: 17)

\section{Öğretmen yeniliğe açık olabilir.}

Katılımcılar tarafından ikinci sırada en fazla yükleme "Öğretmen yeniliğe açık olabilir." temasına yapılmıştır. Bu noktada katılımcıların duyuşsal alan için öğretmenlere önemli vurgu yaptığı görülmektedir. $\mathrm{Bu}$ temaya referans olan okul yöneticilerin bazı görüşleri şu şekildedir.

Yeniliğe açı öğretmenlerle 1 düşünebilen, 2 özgür, 3 özgüveni tam, 4 problem çözme kabiliyeti gelişmiş ve 5 cesur insanlar yetiştirmekte üstesinden gelinebilir. (Katılımcı numarası: 40)

Ders kitaplarındaki metinler ögrencilere örnek olacak davranışlarla dolu. Fakat bu davranışların kazanılması ne şekilde işlendiğine bağll uygulamalı eğitimlerin, takip edilen davranışların daha etkili olduğunu düşünüyorum. (Katılımcı numarası: 39)

...Ancak eğitim programını değiştirmek ülkemizdeki toplumsal sorunların çözümüne yetmez. İşi eğitim olan herkesin, yani biz 
ögretmenlerin zihniyetinin değiştirilmesi şarttır. Ĕ̆itim programlarını uygulayacak olan biz eğitimciler eski, geleneksel, çağın gerisinde kalmış zihinlerimizi temize çekmezsek, gelişime, değişime, yeniliğe açmazsak bir değil bin eğitim programı toplumsal sorunlarımızın üstesinden gelemez. (Katılımcı numarası: 34)

\section{Âile katılımı să̆lanabilir.}

Çalışma grubundan elde edilen ve önemli sayıda yüklemenin olduğu başka bir tema ise "Âile katılımı sağlanabilir." temasıdır. Bu temaya referans olan görüşlerden birkaçı şunlardır:

Öncelikle ögrrenciye bazı davranışlar ve kurallar âilede ögrretilmeli ve uygulanmalıdir. (Kat1lımc1 numarası: 3)

Öğrenciye verilen davranışlar öncelikle âilede verilmeli. Aile ĕgitilmelidir ve bilinçlendirilmelidir. (Katılımc1 numarası: 4)

...Çünkü ilk eğitim yeri âiledir. Okulda ögrenilen bilgiler, âilede tamamlanmiyorsa yetersiz kalıyor. Bunun için bence evlenecek gençler (yani evliler) en az altı aylık âile ve çocuk eğitimine tâbi tutulmalıdir. (Katılımc1 numaras1: 30)

\section{Uygun model olunabilir.}

Öğretim programlarında toplumsal sorunların üstesinden gelecek birey yetiştirecek kadar yer verilmesine ilişkin yüksek sayıda atıf alan bir tema da "Uygun model olunabilir." temasıdır. Bu temaya aşağıdaki görüşler örnek verilebilir:

Daha fazla hayattan örneklerle ögrrencilerin etkinliklerin merkezinde olmaları ve onlara bizler uygun örnek olmalıyı. (Kat1lımc1 numaras1: 9) 
Kitaplarda, derslerde, toplantılarda, câmilerde vs. söylenenler anlatılanlar hayatta karşılık bulmuyor, bulamıyor, neden model olmuyoruz bu konuda? (Kat1lımc1 numaras1: 12)

Pratikte bir şeyler kazandırmak önemli. Eğitimcilerin, anne-babaların doğru model olması, hayat içinde bazı kuralların ögretilip bireyin karakterine yedirilmelidir. (Katılımcı numarası: 20)

...Eğer öyle olsaydı toplumda şiddet vak'aları artmazdı. Kitaplara yazmak için, yazarak değil, çocuklarımıza uygulatarak ve onlara model olarak gelecek nesillere bunlart aktarırız. Ama bundan önce o kitabı hazırlayanlar toplumsal olaylara duyarlı olmalı ilk başta. Başkasından bekleyerek taşıma suyu ile değirmen dönmez, bu iş olmaz. (Katılımcı numarası: 19)

Toplumsal sorunların üstesinden gelecek birey yetiştirecek kadar, öğretim programlarında duyuşsal alana yeteri kadar yer verilmediğini belirten katılımcıların görüşleri doğrultusunda elde edilen diğer temalar şunlardır. Önemli sayıdaki katılımcının görüşü doğrultusunda "Uygu-

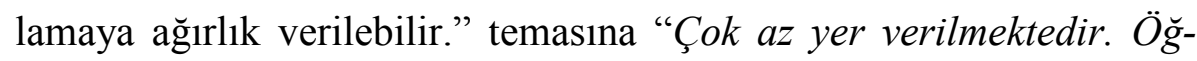
renciler test çözen; ama sorun çözemeyen bireylerdir. Yaparak-yaşayarak öğrenme etkinlikleri yaptırılmalıdır. Ancak en önemlisi uygulamaya ă̆ırlık verilmelidir." (Katılımcı numarası: 29) görüşü örnek gösterilebilir. Önemli sayıdaki katılımcının görüşü doğrultusunda elde edilen başka bir tema ise "Örnek şahsiyetler model gösterilebilir." temasıdır. "Sinıf seviyelerine göre toplumsal sorunlar tespit edilmeli, iyi örneklerle model olarak ögrencilere sunulmal, onlara örnek şahsiyetler gösterilmelidir. Öğrenciliğimde Türkçe ders kitabındaki 'Millet Malı' metnini hâlâ hatırlarım. Tarihten örnekler veri- 
lerek üzerinde durulması gereken hususlar, şiir, makale, anılarla desteklenmelidir." (Katılımcı numarası: 22) görüşü ilgili temayı nitelendirici özellik taşımaktadır. Bazı katılımcıların önerilerinden elde edilen “Ders dışı etkinlik yapılabilir.” temasını "Ne yazık ki yıllık plânı yetiştirme kaygısı içinde bireylere duyuşsal bazı birikimleri aktaramıyoruz. Ders saatleri dışında bu eksiklikler giderilmeli." (Katılımcı numarası: 10) önermesi temsil edebilir.

Diğer temalara göre daha az sayıdaki katılımcının görüşleri doğrultusunda elde edilen temalar da bulunmaktadır. Bu bağlamda "Ders konulabilir." temasını "Ders temelde 2 saat olmalı. Seçmeli olarak 5'e tamamlanmall. Temel matematik gören ögrencilere bilgi yüklenmesi yapmaktan ziyade davranış kazandırılmaya çalışılmalı." (Katılımcı numarası: 5) görüşü nitelerken, "Konu eklenebilir." temasina "Ders programlarında maalesef bu konulara yer verilmiyor. Bizim dersimiz gereği bazen bu konulara değiniyoruz, duyuşsal alan konuları eklenmelidir." (Katılımc1 numarası: 8) önermesi örnek gösterilebilir. Konuyla ilgili olan diğer temalar olan "Öğretim yöntemi değişebilir." temasını “...Daha çok deneye, daha çok gözleme ve gezi programlarına fazla prosedür olmadan, çocuklarının birbirlerini sevgi ve saygı bă̆larının kuvvetlendirecek şekilde ve kitap okuma alışkanlıklarını artıracak çalışmalarla desteklenmeli. İşin özü yöntem değişikliğinde bence." (Katılımcı numarası: 42) görüşü; "Eğitim sistemi değişebilir." temasına “...Sınıfta kalmanın olmaması, velilere çok hak verilmesi, disiplin cezalarının olmaması, başarının ödüllendirilmemesi, velinin çocuk ĕgitimi açısından yetersiz olması eğitime engeldir. Sistem de- 
ğişmelidir. Eğitim olmayınca öğretimde tam olmamaktadır." (Kattlımc1 numarası: 26) fikri; "Ar-ge kurulabilir." temasına ise "...Arge çalışanları kurumları içinde bağımsız, sadece bu işle ilgilenmelidirler." (Katılımcı numarası: 2) önermesi örnek gösterilebilir.

\section{Evet, yer verilmektedir. Çünkü...}

Çalışma grubunda yer alan bazı öğretmenler, toplumsal sorunların üstesinden gelecek birey yetiştirecek kadar öğretim programlarında duyuşsal alana yeteri kadar yer verildiğini ileri sürmüş ve elde edilen görüşlerin analizi sonucunda oluşturulan temalara aşağıda ver verilmiştir.

\section{Kamu kurumları destekliyor.}

Görüşlerin analizi sonucunda yeterli görülen temanın içerinde en fazla yüklemenin "Kamu kurumları destekliyor." temasına yapıldığı tespit edilmiştir. Dolayısıyla sayıca az da olsa, bazı öğretmenlerin, kamu kurumları tarafindan yapılan etkinliklerin duyuşsal alana katkı sağladığını ileri sürmektedir. İlgili temaya referans olan katılımcıların bazılarının görüşleri aşağıda örneklendirilmiştir:

Tam anlamiyla da olmasa verilmektedir. Özellikle belediyelerin yaptığl Sedep, Medeniyet okulu gibi projeler katkı sağllyor. (Katılımc1 numarasi: 7)

Değerler eğitimi olsun SEDEP olsun bunlar önemli insanlara daha fazla yer verilir. (Katılımcı numarası: 11) 


\section{Ders kitapları yeterlidir.}

Katılımcıların bazıları, ders kitaplarının duyuşsal alana yeteri kadar yer verdiği görüşünde birleşmiştir. Bu temaya referans olan görüşler aşağıda yer almaktadır.

...Ders kitaplarında, etkinlikler de duyuşsal alana yer verildiğini düşünüyorum. (Kat1lımc1 numarası: 14)

Ĕ̈itim programları son yıllarda çă̆ın gereklerine göre bir revizyona uğramıştır. Değerler eğitimine ve duyuşsal alana eskiye nazaran daha fazla önem verilmekte bunun için birçok etkinlik düzenlenmektedir... (Katılımc1 numarası: 34)

\section{Bir Öğretmenin Duyuşsal Alana Yönelik Görevlerine İlişkin Çö- zümlemeler}

Duyuşsal alan açısından bir öğretmenin görevlerine ilişkin ilişkin elde edilen görüşlerin içerik analiziyle çözümlemesi sonucunda oluşturulan model Şekil 4'te yer almaktadır. Bunun yanı sıra öğretmenlerin duyuşsal alan açısından görevinin olmasına veya olmamasına ilişkin belirtilen görüşlerden oluşturan ve yükleme sayısı en fazla olan temalar ile bu temalar içerisinde yer alan görüşler aşağıda detaylı olarak betimlenmiştir. 


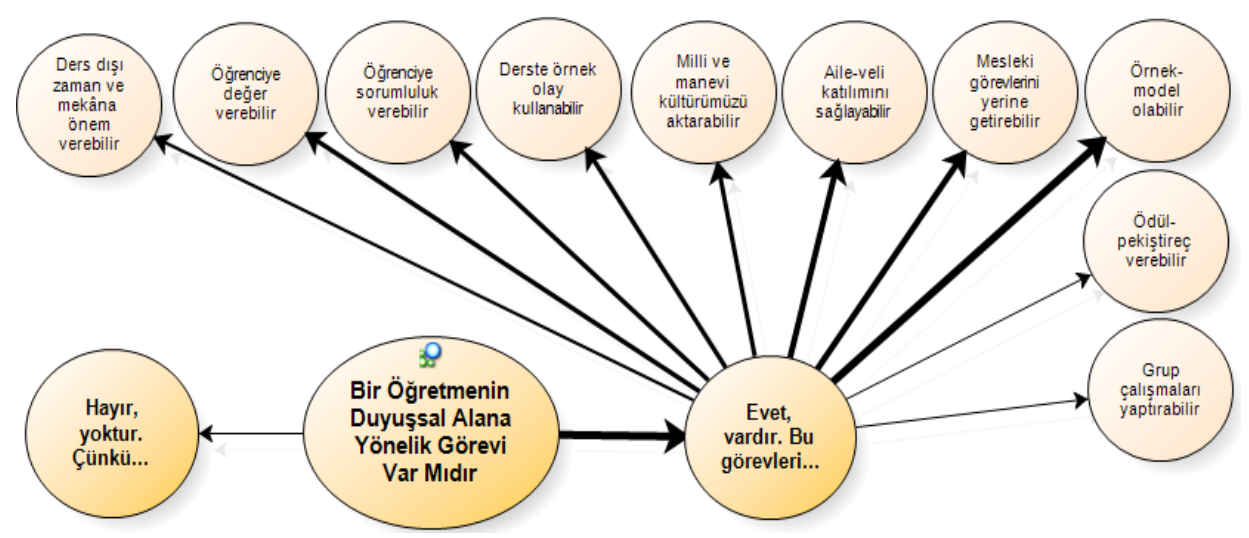

Şekil 4. Bir öğretmenin duyuşsal alana yönelik görevlerine ilişkin şematik gösterim.

\section{Evet, vardır. Bu görevleri...}

Çalışma grubunda yer alan öğretmenlerin görüşleri, bir öğretmenin duyuşsal alana yönelik görevlerinin olduğunu ortaya koymaktadır. Verilerin çözümlenmesi sonucunda elde edilen temalara aşağıda ver verilmiştir.

\section{Örnek-model olabilir.}

Bir öğretmenin duyuşsal alana yönelik görevlerine ilişkin elde edilen veriler 1şığında en fazla yüklemenin "Örnek-model olabilir." temasına yapıldığı tespit edilmiştir. Bu bağlamda katılımcıların görüşlerine göre, öğretmenlerin duyuşsal alan açısından en büyük görevi, onların öğrencilere örnek (model) olması gerektiğine işaret etmektedir. $\mathrm{Bu}$ temaya referans olan öğretmenlerin bazılarının görüşleri aşağıda örneklendirilmiştir.

Öğrencileri kurallara uymaları için uyarmak. Öğrencilere örnek olmak, yeri geldiğinde örnekler vermek.(Katılımcı numarası: 3) 
Ahlâkî değerleri ögrencilere örnek olacak şekilde önem vermek, onlara doğru rol model olmak. Değerler ĕ̆itimine sıkça vurgu yapmak. (Katılımcı numarası: 18)

Kılık kıyafetinden, konuşmasından, temizlik açısından sevgi, saygl, haksızlık, yardımlaşma her yönden öğretmen ögrencilere model olmalıdır. (Katılımcı numarası: 32)

Önce kendisi vermek istediği davranışta örnek almalldır.(Gereksiz akan suyun kapatılması, güneşli bir günde lambaların yakılmaması, sigara içilmemesi vs) selamlaşmak konusu işleyen bir öğretmen dışarıda selam vermiyorsa verdiği bütün eğitim boşa gitmiş demektir. (Katılımcı numarası: 39)

\section{Âile-veli katılımını sağlayabilir.}

Öğretmenler tarafından ikinci sırada en fazla yükleme, “Âile-veli katılımını sağlayabilir.” temasına yapılmıştır. Bu noktada öğretmenlerin, duyuşsal alana ilişkin en önemli görevleri arasında, eğitim sürecine âile ve veli katılını da sağlamasıdır. Bu temaya referans olan görülerden bazıları şu şekildedir:

Veli-ögrenci-öğretmen bütünleşmesi săglanmalıdır. Öğretmen, veli-öğrenci ve devlet arasında bir nevi kordon bă̆l görevi üstlenmelidir. Hatta bu bütünleşme için okul içinde sadece velilerle özel ilgilenen bir öğretmen grubu oluşturulmalıdır. (Halkla ilişkiler benzeri) (Kat11ımcı numarası: 2)

Sevgi, saygl, yardımlaşma, dayanışma ve onlara rol model olarak ögretmenin yaptıklarlyla göstermesi. Aile ziyaretleri ve veli görüşmesine ağırlık verilmeli, beraber sene başı ve sene sonu etkinlikleri ile ögretmene sevgi ve güvenin artırllması să̆lanmalldir. (Katılımc1 numarası: 42) 


\section{Meslekî görevlerini yerine getirebilir.}

Öğretmenlerin duyuşsal alana ilişkin görevleri arasında "Meslekî görevlerini yerine getirebilir.” teması da en fazla yükleme alan temalar arasında yer almaktadır. Bu temaya referans olan katılımcıların bazılarının görüşlerine aşağıda yer verilmiştir.

...Işsini çok sevmeli. Meslekte iyi yetiştirmeli gerekirse yapması gerekenden daha fedakârlık yapmalı, ya da mesleği neyi gerektiriyorsa onu yapmal, sorun çözülür. (Katılımcı numarası: 35)

Türk millî eğitiminin (1739 sayıl yasa ilk 3 madde) genel amaçları bu konuda gâyet açık ve net. Bunu yapmamak, aynı zamanda yasaya uymamaktır. Aynı zamanda da öğretmenliğin gereğini yapmaktır. Ama anket yapsak bu üç maddeyi kaç kişi okumuş/okumamıştır. Bu üç maddenin üzerinde dursak (durmak yasal görevimiz) sonuç nasıl olur? (Katılımcı numarası: 22)

Bir öğretmenin duyuşsal alana yönelik görevlerinin olduğunu belirten ve önemli sayıdaki öğretmen tarafından dile getirilen görüşlerden elde edilen temalar da oluşturulmuştur. $\mathrm{Bu}$ temalardan biri olan "Öğrenciye değer verebilir." temasına "Öğrencileri sevmek, kendi çocuğu gibi davranmak, ona değer vermek, fakat genelde zaten kendi çocuklarımıza da çok kabayız." (Katılımcı numarası: 24) görüşü örnek gösterilebilir. "Öğrenciye sorumluluk verebilir.” temasını ise “Öğrencilere sorumluluk verilmeli ve sorumlulukları anlatmalı ve benimsetmelidir. Sorumluluklarını yerine getiren ve benimseyen ögrenciler, ileride âilesi için, vatanı ve milleti için kendine düşen görev ve sorumluluklarını da yerine getirecektir." (Kat1lımc1 numaras1:41) önermesi nitelemektedir. "Derste örnek olay kullanabilir." temasını “...Öğretmenler, öncelikle davranışlarılla örnek olmalıdırlar. Ancak 
en önemlisi örnek olaylara mutlaka yer vermeliler. Böylece ögrencilerin kişilik gelişmelerini de etkilerler, ögrencilere etkili hikâyeler anlatmalıdırlar. Duyarlılık kazandırmak için, meselâ çevre ile ilgili faaliyetler yapmalıdırlar. Tutum ve davranışlar önemlidir." (Katılımc1 numarası: 29) görüşü temsil edici niteliktedir.

Diğer temalara göre daha az sayıdaki katılımcıların görüşleri doğrultusunda, duyuşsal alana yönelik bir öğretmenin görevleri olduğunu gösteren temalar da belirlenmiştir. "Ders dışı zaman ve mekâna önem verebilir." temasına "Ders saatleri dışındaki zamanlarda ve yerlede ögrretmen öğrenciye bir takım duyuşsal alan içerisinde insanî özellikler kazandırmalı ve onları desteklemelidir." (Katılımcı numaras1: 10) görüşü örnek verilebilir. "Millî ve manevî kültürümüzü aktarabilir." teması ise "Vatana, millete hayırlı nesiller yetiştirmek için çocuklarımıza değerlerimizi ögretmeliyiz. Bu değerlerle birlikte millî ve manevî değerlerimizi çocuklarımıza aktarmalıyız. Geleneklerimizi ögretmeliyiz...” (Katılımc1 numaras1: 11) önermesiyle örtüşmektedir. “Ödül-pekiştireç verebilir.” temasına “Öğrencileri, kurallara uymaları konusunda uyarmak, duyuşsal alanı öğretirken ödül vermek, pekiştireç kullanmak önemli. Âleleri okul kuralları konusunda bilinçlendirmek gerekir. Öğrencileri ödüllendirmek önemli.” (Katılımc1 numarası: 4) görüşü örnek verilebilir. "Grup çalışmaları yaptırabilir.” temasına ise “Kesinlikle duyuşsal alana göre görevleri vardır. Öğrencilerin birlikte hareket etme yetisi, birlikte iş yapması, birlikte ders çalışması, proje yapması, grup olma ve düşüncelerini serbestçe sağlayabilmesi duyuş- 
sal alandaki görevlerdir." (Katılımcı numarası: 7) önermesi referans gösterilebilir.

\section{Bir Öğretmenin Duyuşsal Alana İlişkin Görevlerini Yerine Ge- tirmesinde Karşılaştığı Engellere İlişkin Çözümlemeler}

Duyuşsal alana ilişkin görevlerin yerine getirilmesinde karşılaŞılan engellere ilişkin katılımcıların belirtikleri görüşlerin içerik analiziyle çözümlemesi sonucunda elde edilen model Şekil 5 'te yer almaktadir.

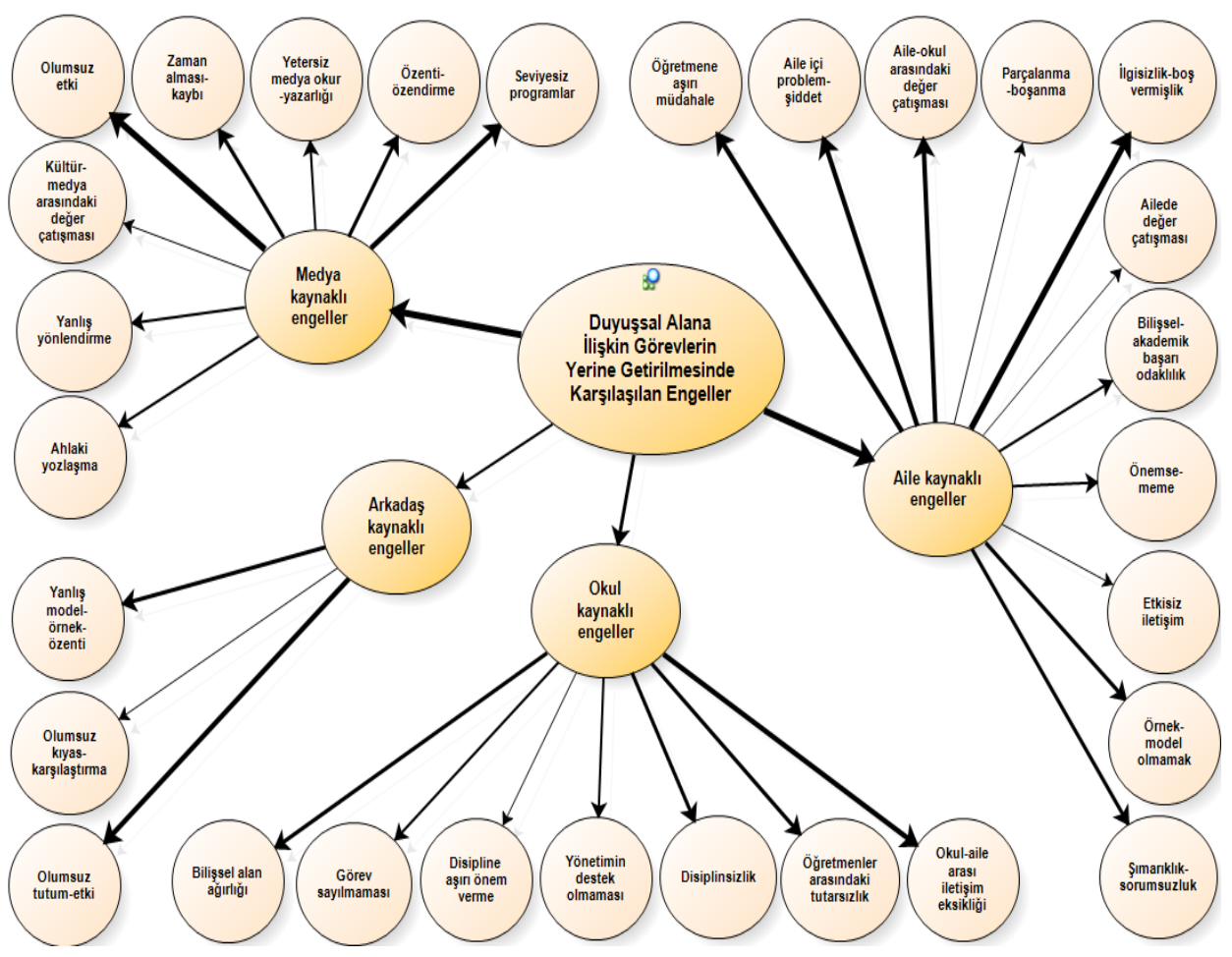

Şekil 5. Bir öğretmenin duyuşsal alana ilişkin görevlerini yerine getirmesinde karşılaştığı engellere ilişsin şematik gösterim. 


\section{Âile kaynaklı engeller}

Katılımcıların görüşlerine dayanarak, bir öğretmenin duyuşsal alana ilişkin görevlerini yerine getirmesinde en büyük engellerin âileden kaynaklandığı tespit edilmiş ve oluşturulan temalara aşağıda ver verilmiştir.

\section{İlgisizlik-boş vermişlik.}

Nitel analiz sonucunda, en fazla yüklemenin "ilgisizlik-boş vermişlik" temasına yapıldığı tespit edilmiştir. Bu bağlamda öğretmenler, âilenin çocuklarına duyuşsal alanda yer alan davranışları kazandırmada ilgisiz veya boş vermiş olduğunu ileri sürmektedir. $\mathrm{Bu}$ temaya referans olan katılımcıların, bazı görüşleri aşağıda örneklendirilmiştir:

Âle ve ögrretmenin yeterli iletişim kuramaması öğretmenin taşıdiğg sosyal kayglların âileye basit görünmesi, âilenin vurdumduymazlığı, kaygısızlı̆̆ vb. bu yüzden âileden destek alamama. (Kat1lımc1 numarası: 18)

Âilesi, kişiyi yetiştirirken ana problemleri çözebileceğine dair özgüven aşılamamış olması öğrencinin yetişme sürecinde âilesi tarafindan ona yeterince ilgi/sevgi saygl gösterilmeyip olumsuz yönlerinin rencide edici şekilde dile getirilmesi. Ailelere bu konuda ilgisiz ve boş vermişlik içinde. (Katılımo numarası: 1)

\section{Ö̆gretmene aşırı müdahale.}

Katılımcılar tarafından ikinci sırada en fazla yükleme "öğretmene aşırı müdahale" temasına yapılmıştır. Bu noktada öğretmenler, duyuşsal alanda üzerine düşen görevleri yerine getirmede âilenin aşırı 
müdahalesi olduğunu vurgulamaktadır. Bu temaya referans olan bazı görüşleri şu şekildedir.

Âle, çocuğunun iyi bir insan olması için gereken uyarllara dahi tepki göstermekte ve yanlış yapmakta. (Katılımcı numarası: 3)

Benim çocuğumdan size ne, benim çocuğum yapmaz, ben çocuğuma güveniyorum vs. şeklinde dönütlerle ögrretmenin elini kolunu bağlıyorlar. (Katılımcı numarası: 17)

Çocuk âilenin temsilcisidir. Alacağınız her kararda âile önünüze bir bariyer koyarsa ve her karar merhalesinde aman bu âilenin tepkisi ne olur diye düşünürsek bu iş olmaz. Bir çeşit mobingtir bu. (Kat1lımc1 numaras1: 18)

\section{Âile-okul arasındaki değer çatışması.}

Nitel analiz sonucunda en fazla yüklemenin olduğu temalarda biri de "âile-okul arasındaki değer çatışması" temasıdır. Bu bağlamda katılımcılar, kimi durum ve zamanlarda âile ile okulun çocuğa farklı uygulama ve muamelede bulunduğunu ileri sürmektedir. $\mathrm{Bu}$ temaya referans olan öğretmenlerin bazılarının görüşleri aşağıda örneklendirilmiştir:

Okulda yanlış olduğu belirtilen bir davranışın âilede normal görülmesi (meselâ sigara veya alkol kullanılması). (Katılımcı numaras1: 39)

Âilenin, kendi kültüründen getirdiği dĕgerlerle öğretmenin kazandırmak isteği hedef değer davranışları arasındaki uyumsuzluk. (Katılımcı numarası: 9)

Aile farklı okul farklı telden çalıyor. Meselâ, toplumsal duyarlılıkla ilgili ögretmenin vermek istediği davranış evde desteklen- 
miyor, dĕger yargıları gibi. Çevre temizliği. (Katılımcı numarası: 29)

\section{Aile içi problem-şiddet.}

Öğretmenler tarafindan en fazla yüklemenin yapıldığı diğer bir yer ise "âile içi problem-şiddet" temasıdır. Bu noktada öğretmenler, âile içerisindeki problemlerin ve âile içi şiddetin, çocukların duyuşsal kazanımlarına engel olduğunu ileri sürmektedir. Bu temaya referans olan katılımcıların bazı görüşleri şu şekildedir:

Âle problemi olan çocuklar hiçbir şeyi umursamıyor Ödevlerini, proje görevlerini yapmiyor, terbiye sınırlarını zorluyor. (Kat1lımcı numarası: 8)

Boşanmış olan, şiddet gören, çeşitli problemleri olan kişilerin çocuklarında da maalesef problemler oluyor. Bunlarla özel ilgilenmeliyiz. Ailede ilgi olmayınca da çocuklarımız problem çıkarabilmekte. (Katılımc1 numarası: 11)

\section{Şımarıklık-sorumsuzluk.}

Katılımcılardan elde edilen verilerin içerik analizi sonucunda “şımarıklık-sorumsuzluk" teması da fazla yüklenmenin yapıldığı temalar arasında yer almaktadır. Bu temaya referans olan katılımcılardan bazılarının görüşleri aşağıda örneklendirilmiştir:

Âlelerin çocuklarını gereğinden fazla şımartıyor, sorumluluk vermiyor, disiplinin olmaması. Anne-baba davranışlarıyla örnek olamıyor, doğruyu yanlışı öğretememesi. Çocuk yanlışla karşılaşınca onun doğru olmadığını bilmesi. (Katılımcı numarası: 27)

Âleler çocukları için fazla hoşgörülü davranıyorlar. Âile içinde disiplin sağlanamıyor. Şimdiden çocuklarına söz geçiremiyor, doğruları ögretmiyorlar. Maalesef şımarık her istediği (doğru ya 
da yanlış) yapılan çocuklar yetiştiriliyor, sorumluluk yok, şımarıklık çok. (Katılımcı numarası: 41)

\section{Örnek-model olmamak.}

Çalışma gurubu tarafindan en fazla vurgulanan âile kaynaklı engellerden birinin de "örnek-model olmamak" temasında yer aldığ 1 görülmektedir. Bu temaya referans olan görüşlerden bazıları aşağıda verilmiştir:

Âle çocuğuna örnek olarak gerekli sorumluluğu vermeli, gereken uyarlar yapmall; ama en önemlisi uygun rol model olmalldir. (Katılımcı numarası: 44)

Çocuk vaktinin çoğunu âile ortamında geçirir. Biz onların bir dönemini kapsiyoruz ve gelip geçiciyiz. Ben ögrenciye doğruyu, emek vermeyi ögrretiyorum. Ama âilede çocuk yalan görüyor ya da baba hirsızlıktan hapiste meselâ. Kimi örnek alsın çocuk, beni mi, babasını mı? (Katılımcı numarası: 32)

Bir öğretmenin duyuşsal alana yönelik görevlerini yerine getirmesinde karşılaştığı âile kaynaklı engellere ilişkin yükleme sayısı ve hiyerarşik sıra takip edilerek oluşturulan temalar ise şunlardır. "Bilişsel-akademik başarı odaklılık” teması "Aileler çocuklarını değerlendirirken akademik başarıyı baz alırlar. Okulda kazanılan davranış, duyuşsal gelişimi çok önemsediklerini düşünmüyorum.” (Katılımc1 numarası: 5) görüşüyle örtüşmektedir. "Önemsememe” temasına "Kesinlikle önemli, sizin derste yaptı̆̆ınızı duyuşsal alanla ilgili tutum âile tarafindan yapılmadı̆̆ında ya da desteklenmediğinde herhangi bir fayda sağlamıyor." (Katılımcı numarası: 7) önermesi örnek gösterilebilir. "Âilede değer çatışması” temasını "Çocuğunu nasıl yetiştirece- 
ğini bilmiyor. Anne siyah derken baba beyaz demektedir. Biri desteklerken diğer bağırıp çağırmakta veya dövmektedir." (Katılımcı numaras1: 7) görüşü temsil etmektedir. Öte yandan "Etkisiz iletişim” temas1 “Çocuklarımızın önemli kısmının âileleri ile sağlıklı iletişimi yok, iletişimi televizyona bırakmışlar." (Katılımcı numarası: 16) görüşüyle örtüşürken, "Parçalanma-boşanma" teması "Anne-baba arasında yaşanan sıkıntılar, boşanmalar, parçalanmış âileleri olumsuz etkiler." (Katılımcı numarası: 22) önermesiyle doğrulanmaktadır.

\section{Medya kaynaklı engeller}

Çalışma grubunda yer alan öğretmenlerin görüşleri doğrultusunda, bir öğretmenin duyuşsal alana ilişkin görevlerini yerine getirmesinde, diğer en büyük engellerin medyadan kaynaklı olduğu ortaya çıkmıştır. İlgili kategori için görüşlerin analizi sonucunda oluşturulan temalara aşağıda değinilmiştir.

\section{Olumsuz etki.}

Öğretmenlerden elde edilen görüşlerin içerik analizi sonucunda en fazla yüklemenin "Olumsuz etki”" temasına yapıldığı ortaya çıkmıştır. Dolayısıyla medyanın çocuklar üzerindeki olumsuz etkisi, onların duyuşsal alandaki kazanımları elde etmelerinde medya kaynaklı en büyük engel olduğu görülmektedir. Bu temaya referans olan katılımcıların bazılarının görüşleri aşağıda örneklendirilmiştir.

Üzülerek söylüyorum tv, internet ve diğerleri ögretmenden daha etkili hâle geldiler. Kötü sayfalara girerek olumsuz davranışlar edinebiliyor ögrenciler. Bunun engellenmesi gerekir. (Katılımc1 numaras1: 8) 
Ö̆grenciler teknoloji merakı yüzünden sorumluluklarını yerine getirememekte, aşırı bağımlı hale gelmekte, zaman israfi, sosyalleşememe, dikkat dă̆ınıklı̆̆ gibi sonuçlar meydana gelmektedir. (Katılımc1 numarası: 30)

Illetişim araçları (televizyon, bilgisayar oyunları) çocukları olumsuz yönde etkilemektedir. Bilgisayar oyunlarından etkilenen çocuklar kavgacı, dövüşen, her zaman kendini haklı olacă̆ını düşünen bireyler olarak yetişmektedirler. (Katılımcı numarası: 41)

Gelişen teknoloji internet ve özellikle tv ve tv dizileri çocuklarlmızın birinci eğitimcisi hâline geldi. Çocuklar, internet siteleri (face) ya da tv başında çok vakit harcar hâle geldi. Dolayısıla orda ne görürse onlar yapar hâle geldiler, onlar da çocukları genellikle olumsuz etkiledi. (Kat1lımc1 numarası: 17)

\section{Seviyesiz programlar.}

Katılımcılar tarafından ikinci sırada en fazla yükleme "seviyesiz programlar" temasına yapılmıştır. Bu noktada öğretmenler, medyada yer alan programların seviyesinin çocukların duyuşsal alanına olumsuz tesir ettiğine işaret etmektedir. İlgili temaya referans olan bazı görüşler şu şekildedir:

Değerler ve ahlâkî kurallara ters düşen yayınların yapılması. (Katılımcı numarası: 14)

Televizyon programları, dizileri çocukların davranışlarını olumsuz etkiliyor. Küfürlü konuşmalar, değişik hareketler... Bilgisayar oyunları insanın değerini düşürüyor. (Katılımcı numaras1: 29)

Medyada insana saygll ve seviyeli programlar yerine psikolojiyi olumsuz etkileyecek programların sıkça yer alması ve öğretmenin 
seçici davranmaksızın kimi zaman/çoğu zaman bu programları takibi. (Kat1lımc1 numarası: 1)

Duyuşsal alana yönelik görevlerini yerine getirmesinde bir öğretmenin medya kaynaklı karşılaştı̆ğ engellere ilişkin yükleme sayısı ve hiyerarşik sıra dikkate alınarak oluşturulan temalar şöyledir. “Özenti-özendirme” teması "Birçok iletişim aracının okuldaki eğitim faaliyetlerini resetlemesi, bu araçların denetimsizliği, eğitimi olumsuz etkiliyor. Siz çocuğa cipsin zararlarını anlatın; reklamlar özendirsin, siz çocuğa örnek ögrenci profili çizin; çocuk okul dizilerindeki ögrenciye benzesin, ilginç." (Katılımc1 numarası: 22) görüşüyle örtüşmektedir. "Zaman alması-kaybı" teması "İletişim araçlarının bireylerin(ögrretmenlerin) hayatında büyük bir yer kaplaması da yine ögretmenleri bu alanda zayıflatır." (Katılımcı numarası: 29) önermesiyle nitelenmektedir. "Yetersiz medya okur-yazarlığı" teması "Program seçilmemesi her şeyin bilinçsizce seyredilmesi, internette savaş oyunları, haberlerde cinayetler, kavgalar, çocukları şiddete itiyor, ne seyredilir ne dinlenir ne oynanır bilmiyoruz." (Kat1lımc1 numaras1: 26) önermesiyle mesajını iletmektedir. "Ahlâkî yozlaşma” teması "Ahlâkımızı bozan programlar, ögrencilerimizin seviyesine uygun olmayan programlar, ahlâk gitti ve biz yozlaştık gibi." (Katılımc1 numarası: 11) görüşüyle örtüşmektedir. "Yanlış yönlendirme" temasına “Aynı şeyi söyleyen, pek çok araç... Gerçek duyarlılık alanlarından uzak, yanlış yönlendiren ya da etkisiz iletişim gereçleri, neye inanacağlz, hep yanlılık dolu tv.” (Katılımc1 numarası: 27) fikri örnek gösterilebilir. "Kültür ve medya arasındaki değer çatışması" teması ise "Okulda işlediği, öğrendiği etik davranışların televizyon internet ga- 
zetelerde farklı lanse edilmesi; okul başka şey söylüyor medya başka şey." (Katılımcı numarası: 39) görüşüyle nitelendirilebilir.

\section{Okul kaynaklı engeller}

Öğretmenlerin görüşlerine göre, bir öğretmenin duyuşsal alana ilişkin görevlerini yerine getirmesinde okuldan kaynaklı engellerin olduğu da ortaya çıkmıştır. Okul kaynaklı engeller kategorisinde yer alan temalar ve bu temalarla ilgili örneklere aşağıda değinilmiştir.

\section{Okul-âile arası iletişim eksikliği.}

Katılımcılardan elde edilen verilerin içerik analizi sonucunda okul ile âile arasında iletişim eksikliğinin duyuşsal alanda yer alan davranışları kazandırmada oldukça önemli bir engel olduğu tespit edilmiştir. Bu temaya, aşağıda yer alan görüş referans olma özelliği taşımaktadır.

Okul idaresi, veli ve ögrenci arasındaki iletişim eksikliği oldukça yaygın. Bir okul düşünün ki veliyle, bir veli düşünün ki okulla hiç iletişime geçmiyor. Çocuk okulda öldü mü kaldı mı, velinin haberi yok. Öğrenci aç mı susuz mu, okulun haberi yok; çünkü iletişim yok. (Katılımcı numarası: 11)

\section{Bilişsel alan ăğırlı̆̆ı.}

Çalışma gurubu tarafından okul kaynaklı önemli engellerden biri de okulun bilişsel alana ve öğrencinin başarısına ağrılık verdiği şeklidedir. Aşağıda yer alan görüş, bu temayı yansıtma özelliği taşımaktadir:

Ĕ̈itim-öğretim programları o kadar dolu ki duyuşsal alanlara ilişkin çalışmaları yetiştirecek zaman çok kısıtlı. Bu zamanda 
okul, kitabî bilgilere ăgırlık veriyor, TEOG sınavı ve bu sınavdaki başarı tek kritedir diyebilirim. Varsa yoksa; başarı, başarı, başarı. (Katılımcı numarası: 25)

\section{Disiplinsizlik.}

Nitel analiz sonucunda önemli sayıda yüklemenin "disiplinsizlik" temasına yapıldığg tespit edilmiştir. Bu bağlamda öğretmenler, okulların disiplinden mahrum olduğunu ve bunun öğrencilere duyuşsal davranış kazandırmada önemli bir engel teşkil ettiğini öne sürmektedir. Bu temaya aşağıda yer alan görüş referans olma özelliği taşımaktadır:

Okulda çocuklara yaptırım uygulanmaması, sorumluluğunu yerine getirmeyen ögrencilere, davranışının yanlış olduğunu bilen ögrencilere yaptırım veya ceza uygulanmaması, çocukların "vurdumduymaz" olmasina neden olmaktadır. Okulda disiplin olmazsa, olacă̆ da budur. (Katılımc1 numarası: 41)

\section{Öğretmenler arasındaki tutarsızlık.}

Öğretmenlerden elde edilen verilerin içerik analizi sonucunda, duyuşsal alana verilen önem konusunda öğretmenler arasında tutarsızlık yaşandığ tespit edilmiştir. Bu temaya referans olan öğretmenlerden ikisinin görüşleri aşağıda yer almaktadır:

Okul ortamında gerek akranlar gerekse ögretmenlerin görüşleri arasında çelişki yaşanması. (Katılımcı numarası: 9)

Çalışanlar ve idareciler arasında, özellikle de ögretmenler arasında tutum, görüş ve bakış farkları engel olabilir. Ama bu engeller ortak akılla aşılmall, bireyler sorunun değil; çözümün parçası olmalı. (Katılımcı numarası: 22) 
Bir öğretmenin duyuşsal alana yönelik görevlerini yerine getirmesinde karşılaştığı okul kaynaklı engellere ilişkin yükleme sayısı ve hiyerarşik sıra takip edilerek oluşturulan diğer temalar sırası ile şunlardır. "Yönetimin destek olmaması" teması "Bazen idare, bizi veli ile yüz yüze getirmeyin ya da âilesi düşünmüyorsa, siz de uğraşmayın, şeklindeki dönütlerle ögretmen desteksiz kalıp bir şey yapmaktan vazgeçiyor." (Katılımc1 numarası: 17) fikriyle özdeştir. "Görev sayılmaması” temas1 “Okuldaki bütün personelin gereken önemi ve hassasiyeti göstermemesi, bu alanı görevi olarak görmemesi." (Katılımcı numarası: 34) önermesiyle özetlenebilir. "Disipline aşırı önem verme” teması ise “...En önemlisi okuldaki otorite problemidir. Aşırı disiplin ve otorite sağlamaya çalışan bir öğretmenin duygusal frekans gönderebileceğini düşünmüyorum.” (Katılımc1 numarası: 33) görüşüyle temsil edilebilir.

\section{Arkadaş kaynaklı engeller}

Katılımcıların görüşlerine dayanarak, bir öğretmenin duyuşsal alana ilişkin görevlerini yerine getirmesinde kategorik olarak son sırada ise arkadaş kaynaklı engellerin yer aldığ temalara aşağıda ver verilmiştir.

\section{Olumsuz, tutum-etki.}

Katılımcılardan elde edilen verilerin içerik analizi sonucunda, arkadaş çevresinin çocuklar üzerindeki olumsuz tutum ve etkisinin, duyuşsal alanda yer alan davranışları onlara kazandırmada önemli bir engel teşkil ettiği ortaya çıkmıştır. Bu temaya referans olan öğretenlerin bazılarının görüşleri aşağıda örneklendirilmiştir. 
Kötü arkadaş çevresine sâhip kişiler maalesef kötü alışkanlıklara maruz kalıyor. (Katılımc1 numaras1: 8)

Verdiğimiz emekler, ne yazık ki, dışarıda gezdiği arkadaşlar tarafindan yok ediliyor. (Katılımcı numaras1: 10)

Öğrencinin arkadaşları tarafindan alaya alınarak hassasiyetlerinden uzaklaştırılması. (Katılımcı numarası: 18)

Duyuşsal alana yönelik görevlerini yerine getirmesinde bir öğretmenin arkadaş kaynaklı karşılaştığı engellere ilişkin yükleme sayısı ve hiyerarşik sıra dikkate alınarak oluşturulan diğer temalar ise şu şekildedir. "Yanlış model-örnek-özenti” temasına “Özellikle ergenlik döneminde kendi arkadaşlarının tutum ve davranışlarını benimseme, onlara uyma ve onları model alma yanlışlı̆̆ çok fazla." (Katılımcı numarası: 14) görüşü örnek verilebilir. "Olumsuz kıyas-karşılaştırma" teması ise "Ama arkadaşlarımda yapıyor, onları görmüyorsunuz, şeklinde arkadaşları yaparsa kendinin de yapma hakkı olduğunu iddia edip ögretmenin söylediği dikkate alınmıyor. Çocuk kendi hatasını özellikle olumsuz davranış sergileyen arkadaşlarıla kendisini kıyaslıyor ve haklı olmaya çalışıyor." (Katılımcı numarası: 17) görüşüyle örtüşmektedir.

\section{Tartışma ve Sonuç}

Çalışmanın birinci alt amacına ilişkin olarak, toplumda en fazla saygısızlık, bencillik, duyarsızlık, hoşgörüsüzlük, terör, maneviyat eksikliği, trafik, toplumsal şiddet ve ekonomik sorunların görüldüğü tespit edilmiştir. Öte yandan güvensizlik, adaletsizlik, medya sorunu, siyasî gruplaşma, madde bağımlılı̆ğ, ahlâkî yozlaşma, yalan ve çevre 
kirliliği sorunlarının da toplumda sıklıkla görülen sorunlar arasında olduğu belirtilmiştir. Bunların yanı sıra empati eksikliği, âile içi şiddet, cehâlet, hırsızlık, sevgisizlik ve işsizlik de en fazla görülen toplumsal sorunlar arasında yer almıştır. Ayrıca önyargı, küfür-argo, dedikodu, şekilcilik, çocuk istismarı ve çarpık kentleşme de önemli toplumsal sorunlar arasında ifade edilmiştir. Diğer yandan öfke, torpil, yalakal1k-yağcılık ve boşanma da daha az sıklıkla olsa da toplumda yaşanılan sorunlar arasında olduğu sonucuna varılmıştır. Alanyazında yer alan pek çok araştırmanın sonucu, bu araştırmadan elde edilen sonucu destekler nitelik taşımaktadır. Beyaznokta Gelişim Vakfı tarafından yayınlanan bir Kök Sorunlar Hakkında Açıklamalar başlıklı bir çalışmaya göre (2007), sayıları çok olmasına rağmen öncelikli sayılabilecek toplumsal sorun alanlarını; millî bütünlük ile ilgili sorunlar, terör ve anarşi, sağlık sorunları, eğitim sorunları, işsizlik ve ekonomik sorunlar, çeşitli özgürlüklerdeki sınırlamalar, konut sorunları, çevre sorunları, sosyal güvenlik sistemi yetmezliği sorunu, trafik anarşisi sorunu, kültürel yozlaşma sorunu, iş kazaları sorunu ve adaletin geç tecelli etmesi sorunu şeklinde sıralamaktadır. Aynı şekilde, Çetin (2013) tarafından yapılan bir çalışma, öğretmenlerin öğrencilere ilişkin karşılaştıkları istenmeyen davranışlar arasında sınıf kurallarına uymama, küfürlü konuşma, derste izinsiz konuşma, çekingenlik, hiperaktiflik ve dikkat eksikliği, şiddet içerikli televizyon programları seyredilmesinden kaynaklanan sorunlar (tehdit etme) olduğunu ortaya koymaktadır. Konuyla ilgili başka bir araştırmada Çankaya (2011), öğretmen görüşleri çerçevesinde en çok karşılaşılan ve istenmeyen öğrenci davranışlarının öğrenciler arası kavgalar, derse ilgisizlik, öğretmene 
saygısılık, kopya çekmek, sınıf içerisinde gruplaşma, dersin akışını bozmak ve öğrencinin sorumluluk üstlenmekten kaçması olduğunu saptamıştır. Benzer sonuçlar, bazı araştırmacılar tarafından da tespit edilmiştir. Özerkmen (2012), toplumda en fazla yaşanılan sorunların başında şiddetin yer aldığını ortaya koyarken, Keleş (2010), Saygılı ve Gürşimşek (2008) ise, küfürlü (argolu) konuşmanın toplumdaki önemli sorunlar arasında olduğunu belirlemiştir.

"Toplumda görülen sorunlar, katılımcıları rahatsız etmekte midir?” sorusunun yer aldığı araştırmanın ikinci alt amacına ilişkin olarak şu sonuçlara ulaşılmıştır. Toplumda görülen sorunların katılımcıları rahatsız ettiği tespit edilmiştir. Toplumsal çöküşü hızlandırması, bu durumum insanı rahatsız etmesi, sorunların kendi sorunları olması ve nitekim huzurun bozulması toplumsal sorunların öğretmenleri rahatsız etmesinin başlıca nedenlerini oluşturmaktadır. Öte yandan katılımcıların toplumsal sorunlardan rahatsız olmasının diğer nedenlerini ise toplumsal sorunların insana yakışmaması ve hayat hakkını ihlâl etmesi oluşturmuştur.

Çalışmanın üçüncü alt amacına ilişkin olarak, az sayıda öğretmen tarafından, değerler eğitimi, SEDEP vb. projelerle kamu kurumlarının desteklediği ve duyuşsal alanla ilgili ders kitaplarının yeterli olduğu dile getirilmiştir. Ancak, katılımcılar tarafından, ağırlıklı olarak vurgulanan nokta; toplumsal sorunların üstesinden gelecek birey yetiştirecek öğretim programlarında, duyuşsal alana yeteri kadar yer verilmemesidir. Bu eksikliği gidermek için yapılan önerilerin başında öğretim programlarında (derslerde) bilişsel alana verilen yerin azaltılma- 
s1, öğretmenin yeniliğe açık olması, eğitim sürecine âile katılımının sağlanması ve uygun modellere yer verilmesi yer almıştır. Bunları derslerde uygulamaya ağırlık verilmesi, örnek şahsiyetlerin model gösterilmesi ve ders dışı etkinliklerin yapılması önerileri takip etmiştir. Öte yandan duyuşsal alanla ilgili ders ve konu eklenmesi, öğretim yönteminin ve eğitim sisteminin değişmesi ile konu hakkında ar-ge kurulması önerileri de yer almıştır.

Araştırmadan ortaya çıkan öğretim programlarında duyuşsal alana yeteri kadar yer verilmediği sonucu, literatürde duyuşssal alan odaklı yapılan araştırma sonuçlarıyla örtüşmektedir. Otluoğlu (2002) tarafından yapılan araştırmanın sonucunda, ilköğretim programlarında kazandırılması gereken bazı duyuşsal alan davranışlarından söz edildiği; ancak içerikte bu davranışlarla ilgili bölümlere pek yer verilmediği ve bunların nasıl kazandırılabileceği konusunda somut örneklerin bulunmadığı tespit edilmiştir. Araştırmanın sonucunu destekleyici, dikkat çekici ve bir o kadar da şaşırtıcı bir sonuç da Turan (2013) tarafından yapılan araştırmadan elde edilmiştir. İlgili araştırma, din kültürü ve ahlâk bilgisi derslerinde doğrudan ya da dolaylı olarak bazı kazanımlara yer verildiğini, bu kazanımların çok büyük bir kısmının bilişsel alanla ilgili olduğunu, duyuşsal alanla ilgili kazanımların ise toplam müfredât içerisinde yüzde üç gibi küçük bir oranda kaldığını teyit etmektedir. Bunların yanı sıra, alanyazında yer alan pek çok araştırma, öğretim programlarında duyuşsal alana yeteri kadar yer verilmediğini ortaya koymaktadır (Albayrak ve Aydın, 2002; Arslan, Işıksal-Bostan ve Şahin, 2013; Çepni, Ayvacı, Şenel-Çoruhlu ve 
Yamak, 2014; Çiftçi, 2010; Demirbaş ve Yağbasan, 2006; Erdoğan ve Gök, 2011; Gazel ve Erol, 2012; Genç, Tutkun ve Çoruk, 2015; Kayhan ve Tokcan, 2013; Özmen, 1999; Yaşaroğlu, 2013).

"Bir öğretmenin duyuşsal alana yönelik görevleri var mıdır?" sorusunun yer aldığ 1 araştırmanın dördüncü alt amacına ilişsin olarak, öğretmenlerin duyuşsal alana yönelik görevlerinin olduğunu ortaya çıkmıştır. Bu görevlerinin başında duyuşsal alanda yer alan davranışlar bakımından öğretmenin örnek-model olması, duyuşsal eğitim sürecine âile-veli katılımını sağlaması ve konuyla ilgili meslekî görevlerini yerine getirmesi yer almıştır. Bunların yanı sıra öğrenciye değer ve sorumluluk vermesi ile derste örnek olay kullanması da öğretmenin duyuşsal alana ilişkin görevleri arasında gösterilmiştir. Öte yandan ders dışı zaman ve mekâna önem vermesi, millî ve manevî kültürümüzü aktarması, derste ödül-pekiştireç kullanması ve grup çalışmaları yaptırması da duyuşsal alanda davranışların öğrencilere kazandırılmasında öğretmenin görevleri arasında yer almıştır.

Duyuşsal alan bakımından öğretmenlerin rol ve sorumlukları üzerine yapılan araştırmaların ortak sonucu olarak öğretmenin model olması ve âilenin eğitim sürecine katılması yer almaktadır. Güven (2004), öğretmenler üzerinde yürüttüğü bir araştırmanın sonucunda, öğretmenlerin iyi bir model olmasının ve bu özelliklerini öğrencilere yansıtmasının önemini ortaya koymakta ve dostça yaklaşımı, nezâketi, saygıyı, öğrencilerin kişiliklerini göz önünde bulundurmayı ve iyi bir rehber olmayı etkili öğretimin temel ilkeleri olarak belirtmektedir. Duyuşal alan eğitiminde âilenin önemini ortaya koyan başka bir 
araştırmada ise Özdemir (2007), çocukların kişisel ve ahlâkî gelişimine ilişkin bütün sorumlulukları sadece okullara yüklemenin yanlış olduğunu, toplumun bütün katmanlarının bu konuda okula yardımcı olması gerektiğini ileri sürmekte ve çocukların kişisel ve ahlâkî gelişimi için eğitimde okullar ile ebeveynler arasında etkili bir ortak hareket şekli kurulmasının, okul ile toplum arasında yakın bir çalışma ve iş birliği oluşturulmasının yaşadığımız toplumsal değişimin ve çağın bir gereği olduğunu ortaya koymaktadır. Konuyla ilgili yapılan araştırmalar incelendiğinde (Açıkgöz, 2007; Aydın ve Akyol-Gürler, 2013; Çelik ve Yeşilyurt, 2014; Gürdoğan-Bayır, Göz ve Bozkurt, 2014; Habacı, Tanrıkulu, Atıcı, Ürker ve Adıgüzelli, 2013; Karataş, 2013; Kefi, Çeliköz ve Erişen, 2013; Özer ve Gelen, 2008; Şahin, 2011; Yaman, 2012; Yeşilyurt ve Kurt, 2012; Yeşilyurt, 2006, 2011) çocukların (öğrencilerin) duyuşal alanda yer alan davranışları kazanmasında öğretmenin uygun model (örnek) olmasının çok önemli bir faktör olduğu anlaşılmaktadır. Bununla birlikte, âile katılımının çocukların duyuşsal alan eğitimi sürecine oldukça önemli katkısının olduğunu çeşitli araştırmalar ortaya koymaktadır (Ereş, 2009; Kandır ve Alpan, 2008; Kır, 2011; Önder, 2013; Özen, 2011; Seçer, Sar1 ve Olcay, 2006; Taşkın, 2011; Yazar, 2012).

Çalışmanın beşinci alt amacına ilişkin olarak, bir öğretmenin duyuşsal alana ilişkin görevlerini yerine getirmesinde en büyük engellerin âileden ve medyadan kaynaklandığı tespit edilmiş, bunları okul ve arkadaş kaynaklı engellerin takip ettiği ortaya çıkmıştır. Erişti ve Tunca (2012) tarafından benzer amaçla yapılan bir çalışmanın sonu- 
cunda, öğretmenlerin, öğrencilere duyuşsal yeterlikler kazandırma konusunda âileler başta olmak üzere, öğrencilerden, çevresel faktörlerden, görsel ve işitsel medyadan kaynaklanan sorunlar yaşadıkları belirlenmiştir. Aynı çalışmanın sonuçlarına göre, yaşanan bu sorunların giderilebilmesi için âile, öğretmen, okul, öğretim programı, medya vb. bütün değişkenlerin külliyen ele alınması gerektiği üzerinde durulmuştur.

Araştırmanın sonuçları arasında, duyuşsal alana ilişkin görevlerin yerine getirilmesinde âile kaynaklı engellerin başında, âilenin duyuşal alana ilişkin görevlerinde ilgisiz davranması, boş vermişliği, öğretmene aşırı müdahalede bulunması, âile-okul arasındaki değer çatışmasının yaşanması, âile içi problem-şiddetin olması, âilenin çocukları şımarık-sorumsuz şekilde yetiştirmesi ve âilenin çocuklara örnek-model olamaması yer almıştır. Âile kaynaklı bu engelleri, âilenin bilişsel-akademik başarıya odaklanması ve duyuşsal alanı önemsememesi, âile içerisinde değer çatışmasının yaşanması, âilenin çocuklarla etkisiz iletişimi ve âilelerin parçalanması-boşanması takip etmiştir. Konuyla ilgili olarak Erişti ve Tunca (2012) tarafından yapılan bir çalışmanın sonuçlarına göre öğrencilere duyuşsal yeterliklerin kazandırılması sürecini olumsuz yönde etkileyen âile kaynaklı sorunların başında, âilelerin çocuğun duyuşsal gelişimine ilişkin farkındalıklarının olmaması ve âilelerin ekonomik imkânının yetersizliği gelmektedir. Aynı çalışmanın diğer sonuçları arasında âile sorunlarının çocuklara yansıtılması, âileler tarafından merkezî sınavdan başarılı olacakları biçimde test ve sınav başarısına odaklı ders işlenmesi konusunda okula 
ve öğretmenlere baskı yapılması, yaşanan soruna etki eden önemli bir etmen olarak bulunmuştur. Öte yandan Erdem'in (2010) araştırması sonucunda, velilerin öğretmen üzerinde baskı kurmaya çalıştmalarının, Dağlı ve Baysal'ın (2012) çalışması sonucunda ise, disiplin sorunlarının ilk üç nedeni olarak âilelerin çocuklarının eğitimine olan ilgisizliği, âile içi problemler ve âilelerin çocuklarına karşı olumsuz tutum ve davranışlarının yer alması, bu araştırmadan ortaya çıkan sonucu desteklemektedir. Bunların yanı sıra, Yapıcı ve Yapıcı (2003) tarafından yapılan çalışmada velilerin çocuklarına karşı ilgisiz olduğu, okulla iletişim kurmadığ 1 , eğitim seviyesinin düşük olduğu, ekonomik durumlarının kötü olduğu, çocuklarından beklediklerinin sadece yüksek not almaları biçiminde ortaya çıkan sonuçlarının elde edilmesi, konuyla ilgili yapılan araştırma sonuçlarının birbiriyle tutarlı olduğunu göstermektedir.

Öğretmenin duyuşsal alana ilişkin görevlerini yerine getirmesinde, medyadan kaynaklı engellerin başında, medyanın insanlar üzerindeki olumsuz etkisi, medyada seviyesiz programların olması ve çocukları, davranışları uygun olmayan kişilere özendirmesi, yer almıştır. Medya kaynaklı bu engelleri, zaman kaybına yol açması, insanların medya okur-yazarlığı konusunda yetersiz olması, medyanın ahlâkî yozlaşmaya, yanlış yönlendirmeye ve değer çatışmasına sebep olması takip etmiştir. Konuyla ilgili yapılan araştırmalar (Akbulut, 2013; Akçay ve Özcebe, 2012; Aksaçlığlu ve Yılmaz, 2007; Avc1 ve Güçray, 2015; Dolu, Büker ve Uludağ, 2010; Dural ve Dural, 2015; Karagülle ve Çaycı, 2014; Mil ve Şanlı, 2015; Özakar ve Koçak, 2012; 
Taylan, 2011; Uzun, 2014; Yapıc1, 2006; Y1lmaz ve Ersoyol, 2013) benzer sonuçları ortaya koymuş ve bu araştırmadan elde edilen sonuçları destekleyici nitelikte olduğu görülmüştür.

Araştırmanın sonuçları arasında, duyuşsal alana ilişkin görevlerin yerine getirilmesinde okuldan kaynaklı engellerin ilk sıralarında okul-âile arasında iletişim eksikliğinin olması, okulun bilişsel alana önem ve ağırlık vermesi, okuldaki disiplin eksikliğgi, duyuşsal alandaki davranışların önemi ve değerine ilişkin öğretmenler arasındaki tutarsızlık yaşanması yer almıştır. Duyuşsal alana yönelik okul kaynaklı bu engelleri, okul yönetiminin öğretmene destek olmaması, okulun duyuşal alanı görev alanında saymaması ve okulun disipline aşırı önem vermesi, takip etmiştir. Bunun bir sonucu olarak, öğrenciler yoğun bir kaygı yaşamaktadırlar, öğrenme motivasyonları ve ilgileri düşük düzeydedir. $\mathrm{Bu}$ durum duyuşsal yeterliklerin kazandırılması sürecini de olumsuz yönde etkilemektedir. Bu sonuç, özellikle sınanma kaygısının ve akademik başarının yol açtığı sonuçlar bağlamında elde edilen araştırma bulgularıyla (Carbonaro, 2005; Huberty, 2009; LaBillois ve Lagace-Seguin, 2009; Smith, 2009) önemli ölçüde benzerlik göstermektedir. Hem bu çalışmanın sonucu hem de alanyazında yer alan diğer araştırma sonuçları öğretmenlerin, âilelerin, okul yönetiminin ve sosyal çevrenin bilişsel alana ve akademik başarıya odaklandığını ve bu noktalara daha fazla ağrılık verdiğini göstermektedir (Yeşilyurt, 2012). Ancak ister kuramsal ister deneysel ister nicel isterse de nitel özellik taşısın, konuyla ilgili yapılan pek çok birçok çalışmada, öğrencilerin bilişsel alanda başarılı olmalarında 
duyuşsal alan davranışlarına sâhip olmanın önemli bir etken olduğu çok net bir şekilde ifade edilmektedir (Alsop ve Watts, 2000; Aquino, 2011; Bastug, 2014; Demirdağ, 2015; Duit ve Treagust, 2003; Li, 2012; Mubeen, Saeed ve Arif, 2013; Okoro ve Uwah, 2013; Şimşek, 2012; Thompson ve Mintzes, 2002; T1lfarlığlu ve Delbesoğlugil, 2014; Varış ve Cesur, 2012; Yeşilyurt, 2013b, 2014).

Bulgulara dayalı olarak araştırmadan elde edilen başka bir sonuç ise, bir öğretmenin duyuşsal alana ilişkin görevlerini yerine getirmesinde arkadaş kaynaklı engellerin ilk sırasında, öğrencilerin arkadaşlarının olumsuz tutum ve etkisinde kaldığıdır. Duyuşsal alana yönelik arkadaş kaynaklı diğer engelleri ise öğrencilerin yanlış kişileri model, örnek alması, onlara özenmesi ve öğrencilerin kendilerini olumsuz davranış sergileyen arkadaşlarıyla karşılaştırarak kendilerini haklı çıkarma çabası içerisine girmesi tespit edilmiştir. Akran ve arkadaşlar, grup üyeleri için aynı zamanda taklit edilecek modellerdir. Çocuklar, akranlarının hareketlerini seyrederek yeni beceriler kazanır. Örnek alınan akranların, çocukların davranışları üzerinde olumlu veya olumsuz etkisi olduğunu gösteren birçok araştırma mevcuttur (Aslan, 2006; Atıc1, 2014; Cengiz ve İnce, 2013; Çelikkaya ve Filoğlu, 2014; Danış ve Şahbikan, 2014; Erdoğdu, 2010; Kaya ve Tuna, 2008; Özgan, Arslan ve Kara, 2014; Yeşilyurt ve Karakuş, 2011). Akran ve arkadaş çevresinin davranışlarını taklit etmeleri, eğer çevresi ahlâkı bozuk ve uyumsuz davranışlar gösteren kimselerden oluşmuşsa, çocukların ahlâk dışı davranışları alışkanlık hâline getirmelerinin kapısını aralar. Zira gençler, akran ve arkadaşlarının kılavuzluğunu daha çok benimserler 
(Şengün, 2007). Bu bağlamda Yılmaz (2001) tarafından yapılan bir çalışmanın sonuçları, akran etkileşiminin yapıcı etkilerini geliştirme sorumluğunun büyük ölçüde öğretmene düştüğünü, öğretmenlerin, öğrencilerin birbiri ile etkileşimleri için uygun çevre koşullarını sağlaması gerektiğini, etkileşimin karşısındakini kabullenme ve gerektiğinde destekleme esasına dayanmasına özen göstermesini icap ettiğini ortaya koymaktadır.

Araştırmadan elde edilen sonuçlar genel olarak değerlendirildiğinde, başta saygısızlık, bencillik, duyarsızlık, hoşgörüsüzlük, terör, maneviyat eksikliği, trafik, toplumsal şiddet ve ekonomik sorunlar olmak üzere, toplumda çok sayıda sorunun olduğu tespit edilmiştir. Araştırmada elde edilen diğer bir sonuç ise, toplumda yaşanılan bu sorunların, katılımcıları (öğretmenleri) oldukça rahatsız ettiğidir. Öte yandan, öğretim programlarında toplumsal sorunların üstesinden gelecek birey yetiştirecek kadar duyuşsal alana yer verilmediği sonucuna da ulaşılmıştır. Ayrıca, bir öğretmenin bilişsel alanda yer alan davranışları öğrenciler kazandırmak kadar, duyuşsal alanda da yer alan davranışları da öğrencilere kazandırma sorumluluğu olduğu ortaya çıkmıştır. Ancak duyuşsal alanda yer alan davranışları öğrencilere kazandırma sürecinde öğretenlerin başta âile ve medya kaynaklı olmak üzere okul ve arkadaş kaynaklı engellerle karşılaştıkları tespit edilmiştir.

\section{Kaynakça}

Açıkgöz, K. Ü. (2007). Aktif öğrenme. İzmir: Biliş Özel Eğitim Danışmanlık Araştırma Hizmetleri ve Yayın Yazılım. 
Akbaş, O. (2008). Özel öğretim yöntemleriyle sosyal bilgiler öğretimi. B. Tay ve A. Öcal, (Eds.), Sosyal bilgilerde değerler ve ögretimi içinde (344-367). Ankara: Pegem Akademi.

Akbulut, Y. (2013). Çocuk ve ergenlerde bilgisayar ve internet kullanımının gelişimsel sonuçları. Trakya Üniversitesi Eğitim Fakültesi Dergisi, 3(2), 53-68.

Akçay, D. ve Özcebe, H. (2012). Okul öncesi eğitim alan çocukların ve ailelerinin bilgisayar oyunu oynama alışkanlıklarının değerlendirilmesi. Çocuk Dergisi, 12(2), 66-71.

Akpınar, B. (2013). Eğitimde program geliştirme. Ankara: Data Yayınları.

Aksaçlığlu, A. G. ve Yılmaz, B. (2007). Öğrencilerin televizyon izlemeleri ve bilgisayar kullanmalarının okuma alışkanlıkları üzerine etkisi. Türk Kütüphaneciliği, 21(1), 3-28.

Akşid, F. ve Şahin, C. (2011). Coğrafya öğretiminde aktif öğrenmenin akademik başarı ve tutum üzerine etkisi. Batı Anadolu Ĕ̆gitim Bilimleri Dergisi, 2(4), 1-26.

Albayrak, M. ve Aydın, Y. (2002, Eylül). 1983 'ten 2002'ye ilköğretim matematik dersi program1, V. Ulusal Fen Bilimler ve Matematik Eğitimi Kongresi'nde sunulan bildiri, Ankara.

http://old.fedu.metu.edu.tr/ufbmek-5/b_kitabi/PDF/Matematik/B ildiri/t203.pdf

Alsop, S. ve Watts, M. (2000). Facts and feelings: Exploring the affective domain in the learning of physics. Physics Education, 35(2), 132-138.

Aquino, L. B. (2011). Study habits and attitudes of freshmen students: Implications for academic intervention programs. Journal of Language Teaching and Research, 2(5), 1116-1121. 
Arslan, O., Işıksal-Bostan, M. ve Şahin, E. (2013). Origaminin matematik eğitiminde kullanılmasına yönelik inanç ölçeği geliştirilmesi. Hacettepe Üniversitesi Ĕ̈itim Fakültesi Dergisi, 28(2), 44-57.

Aslan, M. Y. (2006). Çocuk suçluluğu hakkında uluslararası ve ulusal hukuk düzenlemeleri. Ankara Barosu Dergisi, 66(4), 88-96.

Atıcı, R. (2014). Sınıf içerisinde öğrenci davranışlarına etki eden etmenler. The Journal of Academic Social Science Studies, 28(2), 413-427.

Avcı, R. ve Güçray, S. S. (2015). Ebeveynler arası çatışma, akran ve medya etkileri ile ergenlerdeki şiddet davranışı arasındaki ilişkiler: Şiddete yönelik tutumların aracı rolü. Kuram ve Uygulamada Ĕ̈itim Bilimleri, 13(4), 1995-2015.

Aydın, M. Z. ve Akyol Gürler, Ş. (2013). Okulda değgerler ĕgitimi. Ankara: Nobel Yayınları.

Ayvacı, H. Ş., Alev, Ş. ve Yıldız, M. (2015). Öğrenme kazanımlarının tasarlanma sürecine ilişkin lisansüstü öğrencilerinin zihinsel modellerini belirlemeye yönelik bir çalışma. Kastamonu Eğitim Fakültesi Dergisi, 23(3), 1013-1030.

Bacanlı, H. (2005). Duyuşsal davranış eğitimi. Ankara: Nobel Yayın Dağıtım.

Bastug, M. (2014). The structural relationship of reading attitude, reading comprehension and academic achievement. International Journal of Social Sciences and Education, 4(4), 931-946.

Başar, T. (2009). 2005 yllı ilköğretim 4. sinıf fen ve teknoloji dersi ögretim programı ĕgitim hedeflerinin taksonomik analizi. Yayımlanmamış Yüksek Lisans Tezi, Gaziosmanpaşa Üniversitesi, Sosyal Bilimler Enstitüsü. 
Büyüköztürk, Ş. (2007). Sosyal bilimler için veri analizi el kitabl. Ankara: Pegem A Yayıncılık.

Kök sorunlar hakkında açıklamalar (2007).

http://www.beyaznokta.org.tr/Ezbersiz_egitim/dosyalar/kok-sor un-kaynak-sorun.pdf

Carbonaro, W. (2005). Tracking, students' effort, and academic achievement. Sociology of Education, 78(1), 27-49.

Cengiz, C. ve İnce, M. L. (2013). Farklı okul ortamlarındaki çocukların okul sonrası fiziksel aktivitelerde algıladıkları öz-yeterlikleri. Yönetim Bilimleri Dergisi, 11, 135-147.

Ceylan, Ş. ve Ömeroğlu, E. (2012). Yaratıcı drama eğitimi alan ve almayan 60-72 aylar arasındaki çocukların sosyal-duygusal davranışlarının bazı değişkenlere göre incelenmesi. Kastamonu Ĕ̈itim Dergisi, 20(1), 63-80.

Çakır, Ö. S., Şahin, T. ve Şahin, B. (2000). İlköğretim 6. sınıf fen bilgisi dersine ilişkin bazı değişkenlerin öğrencilerin duyuşsal özelliklerini açıklama gücü. Hacettepe Üniversitesi Ĕ̈itim Fakültesi Dergisi, 19, 43-49.

Çalışkan, M. (2014). Bilişsel giriş davranışları ve duyuşsal giriş özelliklerinin öğrenme düzeyine etkisi. Kuram ve Uygulamada Ĕ̆itim Bilimleri, 14(5), 1807-1821.

Çankaya, İ. (2011). Sınıf öğretmenlerinin karşılaştıkları istenmeyen öğrenci davranışları ve bu davranışlarla başa çıkma yolları. Turkish Studies, 6(2), 307-316.

Çelen, A., Mirzeoğlu, N. ve Mirzeoğlu, A. D. (2010). Çoklu zekâ kuramı doğrultusunda işlenen beden eğitimi derslerinin öğrencilerin bilişsel, duyuşsal ve devinişsel erişi düzeylerine etkisi. e-Journal of New World Sciences Academy Sports Sciences, 5(4), 251-267. 
Çelik, V. ve Yeşilyurt, E. (2014). Values education on the basis of education administrator, teacher and curricula. Mevlana International Journal of Moral and Values Education, 1(1), 1-19.

Çelikkaya, T. ve Filoğlu, S. (2014). Sosyal bilgiler öğretmenlerinin değere ve değer eğitimine ilişkin görüşleri. Kuram ve Uygulamada Ĕ̈itim Bilimleri, 14(4), 1541-1556.

Çepni, S., Ayvacı, H. Ş., Şenel Çoruhlu, T. ve Yamak, S. (2014). Ortaöğretim 9. sınıf fizik ders kitabının güncellenen 2013 öğretim programında yer alan kazanımlara ve kazanımlarda verilen sinırlamalara uygunluğunun araştırılması. Türk Fen Eğitimi Dergisi, 11(2), 137-160.

Çetin, B. (2013). Sınıfta istenmeyen öğrenci davranışlarıyla ilgili sınıf öğretmenlerinin karşılaştıkları sorunlar ve çözüm önerileri. Ahi Evran Üniversitesi Kırşehir Ĕ̆itim Fakültesi Dergisi, 4(1), 255-269.

Çiftçi, Ö. (2010). İlköğretim Türkçe öğretim programında 5. sınıfa ait okuduğunu anlama kazanımlarının bilişsel beceriler yönünden değerlendirilmesi. Türklük Bilimi Araştırmaları (TÜBAR), 27, 185-200.

Dağl1, A. ve Baysal, N. (2012). İlköğretim öğretmenlerinin sinıfta karşılaştıkları disiplin sorunlarının nedenlerine ilişkin görüşleri. Dicle Üniversitesi Ziya Gökalp Eğitim Fakültesi Dergisi, 18, 259-271.

Danış, M. Z. ve Şahbikan, İ. (2014). Suça sürüklenmiş çocukların yeniden toplumsallaşma sürecinde ve insan hakları bağlamında sosyal hizmet yaklaşımlarının yeri ve önemi. Tarih Okulu Dergisi, 25, 627-651.

Demirbaş, M. ve Yağbasan, R. (2006). Fen bilgisi öğretiminde bilimsel 
tutumların işlevsel önemi ve bilimsel tutum ölçeğinin Türkçeye uyarlanma çalışması. Uludă̆ Üniversitesi Eğitim Fakültesi Dergisi, 19(2), 271-299.

Demirdağ, S. (2015). Öğrencilerin akademik öz-yeterliliklerinin yetenek, ortam ve eğitim kalitesine göre karşılaştırılması. Ĕgitim ve Öğretim Araştırmaları Dergisi, 4(1), 315-323.

Demirel, Ö. (2012). Kuramdan uygulamaya ĕ̆itimde program geliştirme. Ankara: Pegem A Yayıncılı.

Dolu, O., Büker, H. ve Uludağ, Ş. (2010). Şiddet içerikli video oyunlarının çocuklar ve gençler üzerindeki etkileri: saldırganlık, şiddet ve suça dair bir değerlendirme. Adli Bilimler Dergisi, 9(4),54-75.

Duit, R. ve Treagust, D. (2003). Conceptual change: A powerful framework for improving science teaching and learning. International Journal of Science Education, 25(6), 671-688.

Dural, A. B. ve Dural, Ş. (2015). Reklam iletileri çerçevesinde çocuk güvenliği - çocuk hakları ve medya etiği. Elektronik Sosyal Bilimler Dergisi, 14, 186-197.

Erdem, A. R. (2010). Sınıf öğretmenlerinin karşılaştı̆ğ toplumsal sorunlar ve toplumsal sorunların performansına etkisi konusundaki görüşleri. Pamukkale Üniversitesi Ĕ̆itim Fakültesi Dergisi, 28(2), 147-163.

Erden, M. (1998). Eğitimde program değerlendirme. Ankara: An1 Yayıncilik.

Erdoğan, M. (2007). Yeni geliştirilen dördüncü ve beşinci sınıf fen ve teknoloji dersi öğretim programının analizi; nitel bir çalışma. Türk Ë̆itim Bilimleri Dergisi, 5(2), 221-254. 
Erdoğan, T. ve Gök, B. (2011). Türkiye, Finlandiya ve İrlanda ana dili öğretim programlarının karşılaştırılması. Buca Eğitim Fakültesi Dergisi, 29, 1-19.

Erdoğdu, M. Y. (2010, Kasım). Öğrencilerin saldırganlık eğilimlerinin bazı değişkenler açısından incelenmeleri. International Conference on New Trends in Education and Their Implications, Antalya.

http://www.iconte.org/File Upload/ks 59689/File/184.pdf

Ereş, F. (2009). Toplumsal bir sorun: suçlu çocuklar ve ailenin önemi. Aile ve Toplum, 11(5), 88-96.

Erişti, B. ve Tunca, N. (2012). Fen ve teknoloji öğretmenlerinin öğrencilere duyuşsal yeterlikler kazandırma sürecinde yaşadıkları sorunlar ve çözüm önerileri. Uluslararası Ĕgitim Programları ve Öğretim Çalışmaları Dergisi, 2(3), 87-102.

Gazel, A. A. ve Erol, H. (2012). İlköğretim 7. sınıf sosyal bilgiler ders programındaki kazanımların taksonomik açıdan değerlendirilmesi. Kuramsal Eğitimbilim Dergisi, 5(2), 202-222.

Genç, S. Z., Tutkun, T. ve Çoruk, A. (2015). Değer ve eğitimi sorunsalı: sınıf öğretmenlerinin görüsslerine göre durum tespit. $E \breve{g} i-$ timde Kuram ve Uygulama, 11(2), 374-397.

Gömleksiz, M. N. ve Kan, A. Ü. (2012). Eğitimde duyuşsal boyut ve duyuşsal öğrenme. Turkish Studies, 7(1), 1159-1177.

Gömleksiz, M. N. (2003). İngilizce duyuşsal alana ilişkin bir tutum ölçeğinin geçerlik ve güvenirliği. Fırat Üniversitesi Sosyal Bilimler Dergisi, 13(1), 215-226.

Güllü, M., Arslan, C., Uğraş, S. ve Görgüt, İ. (2011). Yeni ortaöğretim beden eğitimi ders programı kazanımlarının değerlendirilmesi. Yüzüncü Yıl Üniversitesi Eğitim Fakültesi Dergisi Özel Sayısı, 
122-133.

http://efdergi.yyu.edu.tr/makaleler/beden/mehmet.pdf

Gürdoğan-Bayır, Ö., Göz, N. L. ve Bozkurt, M. (2014). Sınıf öğretmeni adaylarına göre sosyal bilgiler dersinde küresel vatandaşlık. Ĕgitim Bilimleri Araştırtmaların Dergisi, 4(2), 145-159.

Güven, İ. (2004). Etkili bir öğretim için öğretmenden beklenenler. Milli Ë̆itim Dergisi, 164, 127-142. http://dhgm.meb.gov.tr/yayimlar/dergiler/Milli_Egitim_Dergisi/ 164/guven.htm

Habacı, İ., Tanrikulu, F. Z., Atıcı, R., Ürker, A. ve Adıgüzelli, F. (2013). Sınıf içi disiplin kurallarının benimsetilmesinde öğretmen rolleri. Turkish Studies, 8(8), 1953-1971.

Huberty, T. (2009). Test and performance anxiety. Principle Leadership, 10(1), 12-16.

Kandır, A. ve Alpan, Y. (2008). Okul öncesi dönemde sosyal-duygusal gelişime anne-baba davranışlarının etkisi. Aile ve Toplum, 4, 33-38.

Karagülle, A. E. ve Çaycı, B. (2014). A ̆g toplumunda sosyalleşme ve yabancılaşma. The Turkish Online Journal of Design, Art and Communication, 4(1), 1-9.

Karataş, A. (2013). İlköğretim öğretmen adayları için meslek etiğinin önemi. Marmara Coğrafya Dergisi, 28, 304-318.

Kaya, K. ve Tuna, M. (2008). İlköğretim çağındaki çocukların sosyalleşmesinde televizyonun etkisi. SD ̈̈ Fen Edebiyat Fakültesi Sosyal Bilimler Dergisi, 17, 159-182.

Kayhan, C. ve Tokcan, H. (2013). İlköğretim sosyal bilgiler 4. ve 5. sınıf ünite kazanımları ile ders kitapları hazırlık ve değerlendirme 
sorularının bilişsel, duyuşsal ve psikomotor hedefler açısından karşılaştırılması. The Journal of Academic Social Science Studies, 6(3), 685-700.

Kefi, S., Çeliköz, N. ve Erişen, Y. (2013). Okulöncesi eğitim öğretmenlerinin temel bilimsel süreç becerilerini kullanım düzeyleri. Ĕ̆itim ve Öğretim Araştırmaları Dergisi, 2(2), 300-319.

Keleş, Z. (2010). Illköğretim okulları birinci kademe sınıf ögretmenlerinin sınıf yönetiminde karşılaştıkları istenmeyen ögrenci davranışları ve bu davranışlarla baş etme yöntemleri. Yayımlanmamış yüksek lisans tezi, Yeditepe Üniversitesi, Sosyal bilimler Enstitüsü.

Kır, İ. (2011). Toplumsal bir kurum olarak ailenin işlevleri. Elektronik Sosyal Bilimler Dergisi, 10, 381-404.

LaBillois, J. ve Lagace-Seguin, D. G. (2009). Does a good fit matter? Exploring teaching styles, emotion regulation, and child anxiety in the classroom. Early Child Development and Care, 179(3), 303-315.

Li, L. K. Y. (2012). A study of the attitude, self-efficacy, effort and academic achievement of cityU students towards research methods and statistics. SS Student E-Journal, 1, 154-183.

Mayring, P. (2000). Nitel sosyal araştırmaya giriş. (A. Gümüş ve M. S. Durgun, Çev.). Adana: Baki Kitabevi. (Orijinal çalışma basım tarihi 1996).

MEB. (2015). Millî ĕgitim temel kanunu.

http://mevzuat.meb.gov.tr/html/temkanun0/temel kanun_0.html

Mil, H. İ. ve Şanlı, S. (2015). Sporda şiddet ve medya etkisi: Bir maçın analizi. Elektronik Sosyal Bilimler Dergisi, 14, 231-247. 
Morgil, İ., Güngör-Seyhan, H. ve Seçken, N. (2009). Proje destekli kimya laboratuvarı uygulamalarının bazı bilişsel ve duyuşsal alan bileşenlerine etkisi. Türk Fen Eğitimi Dergisi, 6(1), 89-107.

Mubeen, S., Saeed, S. ve Arif, M. H. (2013). Attitude towards mathematics and academic achievement in mathematics among secondary level boys and girls. Journal of Humanities and Social Science, 6(4), 38-41.

Okoro, C. C. ve Uwah, C. S. (2013). Teacher gender and attitude of primary school pupils to schooling in Uyo Metropolis, Akwa Ibom State, Nigeria. Universal Journal of Psychology, 1(2), 53-58.

Otluoğlu, R. (2002). İlköğretim okulu izlencesinde (programında) duyuşsal alan ve duygu eğitimi. M. U. Atatürk Eğitim Fakültesi Ĕ̈itim Bilimleri Dergisi, 15, 163-172.

Önder, M. (2013). Sevgi, din dili ve hikâyelerin çocukların din eğitimindeki yeri ve önemi. The Journal of Academic Social Science Studies, 6(3), 1285-1298.

Özakar, S. ve Koçak, C. (2012). Kitle iletişim araçlarından televizyonun 3-6 yaş grubundaki çocukların davranışları üzerine etkisi. New/Yeni Symposium Journal, 50(1), 31-40.

Özdemir, M. Ç. (2007). Toplumsal değişme karşısında aile ve okul. Türk Eğitim Bilimleri Dergisi, 5(2), 185-198.

Özdemir, M., Altıok, S. ve Baki, N. (2015). Bloom'un yenilenmiş taksonomisine göre sosyal bilgiler öğretim programı kazanımlarının incelenmesi. Eğitim ve Öğretim Araştırmaları Dergisi, 4(3), 363-375.

Özen, Y. (2011). Etik mi? Ahlak mı? Modernite mi? Medeniyet mi? Değerler eğitimine sosyal psikolojik bir yaklaşım. Dicle Üniver- 
sitesi Sosyal Bilimler Enstitüsü Dergisi, 3(5), 63-87.

Özer, B. ve Gelen, İ. (2008). Öğretmenlik mesleği genel yeterliklerine sahip olma düzeyleri hakkında öğretmen adayları ve öğretmenlerin görüşlerinin değerlendirilmesi. Mustafa Kemal Üniversitesi Sosyal Bilimler Enstitüsü Dergisi, 5(9), 39-55.

Özerkmen, N. (2012). Toplumsal bir olgu olarak şiddet. Akademik Bakış Dergisi, 28, 1-19. http://www.akademikbakis.org/eskisite/28/25.pdf.

Özgan, H., Arslan, M. C. ve Kara, M. (2014). Popüler kültürün öğrenci davranışları üzerinde algılanan etkileri. EKEV Akademi Dergisi, $18,469-484$.

Özmen, F. (1999). Etkili eğitimin gerçekleşmesinde duyuşsal alanın önemi-sevgi eğitimi. Fırat Üniversitesi Sosyal Bilimler Dergisi, 9(1), 193-198.

Saygılı, G. ve Gürşimşek, I. (2008). Sınıfta istenmeyen davranışlara ilişkin öğrenci görüşleri. Dokuz Eylül Üniversitesi Buca Eğitim Fakültesi Dergisi, 23, 152-159.

Secçer, Z., Sari, H. ve Olcay, O. (2006). Anne tutumlarına göre okulöncesi dönemdeki çocukların ahlaki ve sosyal kural bilgilerinin incelenmesi. Selçuk Üniversitesi Sosyal Bilimler Dergisi, 16, 539-557.

Semerci, N. ve Özer, B. (2004, Temmuz). Duyuşsal davranışların kazandırılmasında tarih derslerinin öğretiminin önemi. XIII. Ulusal Ĕgitim Bilimleri Kurultayl, İnönü Üniversitesi, Malatya.

Senemoğlu, N. (2013). Gelişim, ögrenme ve öğretim: Kuramdan uygulamaya. Ankara: Yargı Yayınevi.

Smith, A. (2009). Teaching students in inclusive settings. Toronto: 
Pearson Publishing.

Sönmez, V. (2007). Program geliştirmede öğretmen elkitabı. Ankara: Anı Yayınc1lık.

Sözer, E. (2003). Öğretimde planlama ve değerlendirme. M. Gültekin, (Ed.), Öğretimde amaçlar ve düzenlenmesi içinde (31-44). Eskişehir: Anadolu Üniversitesi Yayınları.

Sünbül, A. M. (2011). Öğretim ilke ve yöntemleri. Konya: Eğitim Yayınevi.

Şahin, A. (2011). Öğretmen algılarına göre etkili öğretmen davranışları. Ahi Evran Üniversitesi Ĕ̆itim Fakültesi Dergisi, 12(1), 239-259.

Şahin, İ. (2007). Yeni ilköğretim 1. kademe Türkçe programının değerlendirilmesi. Illkögretim Online, 6(2), 284-304.

Şengün, M. (2007). Ahlak gelişimin psiko-sosyal dinamikleri. Ondokuz Mayı Üniversitesi İlahiyat Fakültesi Dergisi, 23, 201-221.

Şimsek, A. S. (2012). Bilişsel ve duyuşsal özelliklerin yükseköğretimdeki akademik başarıyı yordama gücü. Yayımlanmamış Yüksek Lisans Tezi, Ankara Üniversitesi, Eğitim Bilimleri Enstitüsü.

Tahaoğlu, A. (2014). Ortaöğretim Türk edebiyatı dersi ögretim programı kazanımlarının bilişsel açıdan incelenmesi. Yayımlanmamış Yüksek Lisans Tezi, Bilkent Üniversitesi, Eğitim Bilimleri Enstitüsü.

Taşkın, N. (2011). Çocukların gelişiminde katkıları unutulanlar: Babalar. Ĕ̈itime Baklş, 7, 43-47.

Taşpınar, M. (2012). Kuramdan uygulamaya öğretim yöntemleri. Ankara: Elhan Kitap Yayın Dağıtım. 
Taylan, H. H. (2011). Televizyon programlarındaki şiddetin yetiştirme etkisi: Konya lise öğrencileri üzerine bir araştırma. http://acikerisim.selcuk.edu.tr:8080/xmlui/handle/123456789/22 28.

Thompson, T. L. ve Mintzes, J. J. (2002). Cognitive structure and the affective domain: On knowing and feeling in biology. International Journal of Science Education, 24(6), 645-660.

T1lfarlıoglu, F. Y. ve Delbesoğlugil, A. B. Ö. (2014). Questioning academic success through self-regulation, self-esteem and attitude in foreign language learning (a case study). Theory and Practice in Language Studies, 4(11), 2223-2230.

Turan, İ. (2013). Gençlik döneminde görülen ahlaki sorunlar karşısında din kültürü ve ahlak bilgisi dersinin yeri. Atatürk Üniversitesi İlahiyat Fakültesi Dergisi, 40, 271-293.

Türnüklü, A. (2004). Okullarda sosyal ve duygusal öğrenme. Kuram ve Uygulamada Eğitim Yönetimi, 37, 136-152.

Uzun, R. (2014). Çocukların medyadan ve medyada korunması: Çocuklara yönelik etik davranış kurallarının incelenmesi. Akdeniz Iletişim, 22, 152-167.

Varış, Y. A. ve Cesur, D. (2012). Ortaöğretim öğrencilerinin müzik dersine ilişkin tutumları ile akademik başarıları arasındaki ilişki. e-Journal of New World Sciences Academy NWSA-Fine Arts, 7(4), 318-333.

Yaman, E. (2012). Değerler ĕgitimi. Ankara: Akçă̆ Yayınları.

Yapıcı, M. ve Yapıcı, Ş. (2003). İlköğretim öğretmenlerinin karş1laştığı sorunlar. Üniversite ve Toplum, 3(3), 1, http://www.universite-toplum.org/text.php3?id=142 adresinden edinilmiştir. 
Yapıcı, Ş. (2006). Bir eğitim aracı olarak televizyon ve etkileri. Üniversite ve Toplum, 6(2), 1, http://www.universite-toplum.org/text.php3?id=272 adresinden edinilmiştir.

Yaşaroğlu, C. (2013). Hayat bilgisi dersi kazanımlarının değerler eğitimi açısından incelenmesi. Turkish Studies, 8(7), 849-858.

Yazar, T. (2012). Öğretmen adaylarının değerler hakkındaki görüşleri. Pegem Ĕ̈itim ve Öğretim Dergisi, 2(1), 61-68.

Yeşilyurt, E. ve Karakuş, M. (2011). Öğretmenlerin adaylık sürecinde karşılaştıkları problemler. International Online Journal of Educational Sciences, 3(1), 261-293.

Yeşilyurt, E. ve Kurt, İ. (2012). Değerleri kazandırmasındaki etkililik açısından resmî ve örtük program ile okul dışı etmenlerin öğrenci görüşleri doğrultusunda değerlendirilmesi. Turkish Studies, 7(4), 3253-3272.

Yeşilyurt, E. (2006). Öğretmenlerin ögretim araç ve gereçlerini kullanma durumlarını etkileyen faktörler. Yayımlanmamış yüksek lisans tezi, Frrat Üniversitesi, Sosyal Bilimler Enstitüsü.

Yeşilyurt, E. (2011). Öğretmen adaylarının öğretmenlik mesleği genel yeterliklerine yönelik yeterlik algıları. Gazi Üniversitesi Türk Ĕ̈itim Bilimleri Dergisi, 9(1), 71-100.

Yeşilyurt, E. (2012). Öğretmen adaylarının bilişsel alanla ilgili sınama durumu soruları yazma yeterliklerinin değerlendirilmesi. Kastamonu Ĕ̆itim Dergisi, 20(2), 519-530.

Yeşilyurt, E. (2013a). Öğretmenlerin öğretim yöntemlerini kullanma amaçları ve karşılaştıkları sorunlar. Atatürk Üniversitesi Sosyal Bilimler Enstitüsü Dergisi, 17(1), 163-188. 
Yeşilyurt, E. (2013b). Academic self-efficacy perceptions of teacher candidates. Mevlana International Journal of Education (MIJE), 3(1), 93-103.

Yeşilyurt, E. (2014). Academic locus of control, academic dishonesty tendencies and test anxiety levels as predictors of academic self-efficacy. Educational Sciences: Theory \& Practice, 14(5), 1945-1956.

Yıldırım, A. ve Şimşek, H. (2006). Sosyal bilimlerde nitel araştırma yöntemleri. Ankara: Seçkin Yayıncılık.

Yıldız, D. G. ve Bümen, N. T. (2013). Kubaşı öğrenme ve anlaşmazlık çözümü eğitimi ile bütünleştirilmiş öğretim programının akademik başarı ve sosyal problem çözme becerisine etkisi. Turkish Journal of Education, 2(4), 28-43.

Yı1maz, A. (2001). Sınıf içi öğrenci - öğrenci etkileşiminin öğrenme ve sosyal gelişim üzerindeki etkileri. Kuram ve Uygulamada Ĕ̆itim Yönetimi, 7(1), 147-158.

Yılmaz, K. ve Ersoyol, H. (2013). Medyanın değişen çocukluğa etkisi konusunda veli, öğretmen ve öğretmen adaylarının görüşleri. The Journal of Academic Social Science Studies, 6(4), 759-777.

Yiğittir, S. ve Kaymakcı, S. (2012). Sosyal bilgiler dersi öğretim programı uygulama kılavuzu'nda yer alan etkinliklerin değer eğitimi yaklaşımları açısından incelenmesi. Ahi Evran Üniversitesi Kırşehir Ĕ̆itim Fakültesi Dergisi, 13(2), 49-73. 